OPEN ACCESS

Edited by:

Bieke Broux,

University of Hasselt, Belgium

Reviewed by:

Ulrich Lothar Maria Eisel, University of Groningen, Netherlands

Robert Adam Harris,

Karolinska Institute (KI), Sweden

*Correspondence:

Kyoungho Suk

ksuk@knu.ac.k

Specialty section

This article was submitted to

Multiple Sclerosis and

Neuroimmunology,

a section of the journal

Frontiers in Immunology

Received: 03 January 2019

Accepted: 30 January 2019

Published: 19 February 2019

Citation:

Lee W-H, Seo D, Lim S-G and Suk K (2019) Reverse Signaling of Tumor Necrosis Factor Superfamily Proteins

in Macrophages and Microglia:

Superfamily Portrait in the Neuroimmune Interface.

Front. Immunol. 10:262 doi: 10.3389/fimmu.2019.00262

\section{Reverse Signaling of Tumor Necrosis Factor Superfamily Proteins in Macrophages and Microglia: Superfamily Portrait in the Neuroimmune Interface}

\author{
Won-Ha Lee ${ }^{1}$, Donggun Seo ${ }^{2}$, Su-Geun Lim ${ }^{1}$ and Kyoungho Suk ${ }^{2 \star}$ \\ ${ }^{1}$ BK21 Plus KNU Creative BioResearch Group, School of Life Sciences, Kyungpook National University, Daegu, South \\ Korea, ${ }^{2}$ BK21 Plus KNU Biomedical Convergence Program, Department of Pharmacology, School of Medicine, Brain \\ Science \& Engineering Institute, Kyungpook National University, Daegu, South Korea
}

The tumor necrosis factor (TNF) superfamily (TNFSF) is a protein superfamily of type II transmembrane proteins commonly containing the TNF homology domain. The superfamily contains more than 20 protein members, which can be released from the cell membrane by proteolytic cleavage. Members of the TNFSF function as cytokines and regulate diverse biological processes, including immune responses, proliferation, differentiation, apoptosis, and embryogenesis, by binding to TNFSF receptors. Many TNFSF proteins are also known to be responsible for the regulation of innate immunity and inflammation. Both receptor-mediated forward signaling and ligand-mediated reverse signaling play important roles in these processes. In this review, we discuss the functional expression and roles of various reverse signaling molecules and pathways of TNFSF members in macrophages and microglia in the central nervous system (CNS). A thorough understanding of the roles of TNFSF ligands and receptors in the activation of macrophages and microglia may improve the treatment of inflammatory diseases in the brain and periphery. In particular, TNFSF reverse signaling in microglia can be exploited to gain further insights into the functions of the neuroimmune interface in physiological and pathological processes in the CNS.

Keywords: tumor necrosis factor superfamily, immunity, inflammation, macrophage, microglia, neuroinflammation, neuroimmune interface

\section{INTRODUCTION}

Cell-to-cell communication, particularly for immune cells, occurs through either soluble mediators or direct contact. In cases of communication through soluble mediators, molecules, such as cytokines, chemokines, and hormones act in an autocrine, paracrine, or endocrine manner to stimulate cell surface receptors. In contrast, direct contact requires the interaction between cell surface molecules, such as cell adhesion molecules. Members of the tumor necrosis factor (TNF) superfamily (TNFSF) constitute a special class of molecules that are involved in both types of cell communication. 
TNFSF members are type II membrane proteins that are present on the cell surface or in intracellular compartments. In their membrane-bound form, TNFSF members can interact with their cognate TNF receptor superfamily (TNFRSF) members present on the cell surface or on adjacent cells. Cellular activation increases cell surface expression and secretion of homotrimeric forms of TNFSF members released from the cell surface. For TNF- $\alpha$, this proteolytic cleavage is carried out by TNF- $\alpha$-converting enzyme, a member of the ADAM family of metalloproteases. Released trimeric forms of these ligands then act as cytokines by interacting with their cognate receptors.

Increasing evidence has demonstrated that during direct contact within or among cells expressing TNFSF and TNFRSF members, signals are generated from the receptor part (forward signaling) as well as the ligand part (reverse signaling). Another interesting feature of the interactions between TNFSF/TNFRSF members is that there is substantial crosstalk among cognate ligand-receptor pairs, and some receptors can also be solubilized and released into the surrounding tissues, thereby serving as competitive inhibitors of ligand action on receptor-bearing cells $(1,2)$.

Macrophages are immune cells that express most members of the TNFSF and TNFRSF before and/or after activation. Macrophages perform immunoregulatory functions at sites of acute and chronic inflammation, pathogenesis, and tumorigenesis. Many of the functions of macrophages are mediated by TNFSF and TNFRSF members. Moreover, TNFSF and TNFRSF members are expressed in brain glial cells and mediate diverse biological effects, including neuroinflammation and cell death. Neuroinflammation is closely associated with diverse neuropathologies, such as CNS injury and neurodegenerative diseases (3). Recent evidence indicates that neuroinflammation is one of the major components of the disease mechanisms. Under pathological conditions, neuroinflammation and brain injury constitute a positive feedback loop that perpetuates damages in the nervous system. Brain glial cells, particularly microglia, play a pivotal role in these processes. Inflammatory and neurotoxic mediators produced from excessively activated microglia contribute to neurodegeneration. Intracellular and intercellular signaling of microglia has been proposed as a therapeutic target to dampen deleterious microglial activation and to protect neurons from microglial neurotoxicity (4-6). In that vein, TNFSF and TNFRSF members expressed in brain microglia may provide insights into the intercellular signaling of microglia, and shed light on the regulatory mechanisms of microglia-mediated neuroinflammation.

To date, many reviews have summarized the roles of forward signaling in various processes associated with normal immunity and the pathogenesis of cancer and other conditions. Therefore, in this review, we will focus on reverse signaling initiated from membrane-bound form of TNFSF with an emphasis on recent developments. Especially, members of TNFSF that are expressed in macrophage/microglial lineage cells, such as BAFF/APRIL, LIGHT, GITRL, FasL, TWEAK, and CD137L (4-1BBL), will be the main topic of this review.

\section{B-CALL ACTIVATION FACTOR OF THE TNF FAMILY (BAFF)/A PROLIFERATION-INDUCING LIGAND (APRIL)}

BAFF (also known as TALL-1, THANK, and TNFSF13B), a Bcell survival factor, and its close relative APRIL (also known as TNFSF13) are expressed in both membrane-bound and soluble forms in various cells lineages, including myeloid cells (monocytes, macrophages/microglia, neutrophils, and dendritic cells [DCs]), stromal cells within lymphoid organs, and osteoclasts (7-10). APRIL shares $\sim 30 \%$ sequence identity with BAFF in the TNF domain (11). BAFF interacts with three types of receptors: transmembrane activator and a calcium-modulating cyclophilin ligand interactor (TACI), B-cell maturation antigen (BCMA), and BAFF receptor (BAFFR and BR3; Figure 1). These receptors can be found in lymphoid cells (i.e., B cells and plasma cells, but also in some subsets of $\mathrm{T}$ cells) and myeloid cells $(8,10)$. Although BAFF-R interacts with only BAFF, TACI, and BCMA interact with both BAFF and APRIL. Studies of APRIL and $\mathrm{BAFF}$ transgenic/knockout mice have revealed that these molecules are essential for B-cell survival, T-cell costimulation, autoimmune diseases, and cancer (8-11). Moreover, ligation of BAFFR activates B-cell survival through activation of the nuclear factor (NF)- $\kappa \mathrm{B}$ pathway and downstream anti-apoptotic genes $(12,13)$. Although both BAFF and APRIL are required for Bcell maturation and survival, BAFF has major effects on preimmune B cells, whereas APRIL acts on antigen-experienced B cells (14).

Both BAFF and APRIL contain a short cytoplasmic region of $\sim 30$ amino acids, a transmembrane domain (TMD), and a 200-residue extracellular domain consisting of a stalk and a TNF domain (11, 15-17). In macrophages, both are capable of inducing reverse signaling, which triggers inflammatory changes for the induction of various inflammatory mediators, including matrix-degrading enzymes and pro-inflammatory cytokines $(18,19)$. Treatment of either primary mouse macrophages or human macrophage-like cell lines with the TACI:Fc fusion protein or anti-BAFF/APRIL-specific monoclonal antibodies (mAbs) stimulates the cells to express various pro-inflammatory markers while suppressing cytoskeletal rearrangement associated with phagocytosis and transmigration (18-21). Furthermore, co-incubation with Ramos cells, which express both TACI and BCMA, results in pro-inflammatory activation of THP1 cells in a BAFF- or APRIL-dependent manner, indicating that cell-to-cell interactions can stimulate BAFF- or APRILmediated reverse signaling $(18,21)$. These pro-inflammatory responses initiated by BAFF are mediated by the mitogenactivated protein kinase (MAPK) extracellular signal-regulated kinase (ERK) and NF- $\mathrm{B}$, and suppression of cytoskeletal rearrangement is mediated by phosphatidylinositol 3-kinase (PI3K)/AKT and Rac-1, a Rho-family GTPase. Interestingly, BAFF-mediated signaling shows significant crosstalk with Tolllike receptor (TLR) 4-mediated signaling such that simultaneous treatment with anti-BAFF mAbs and lipopolysaccharide (LPS) results in a synergistic response with respect to pro-inflammatory 


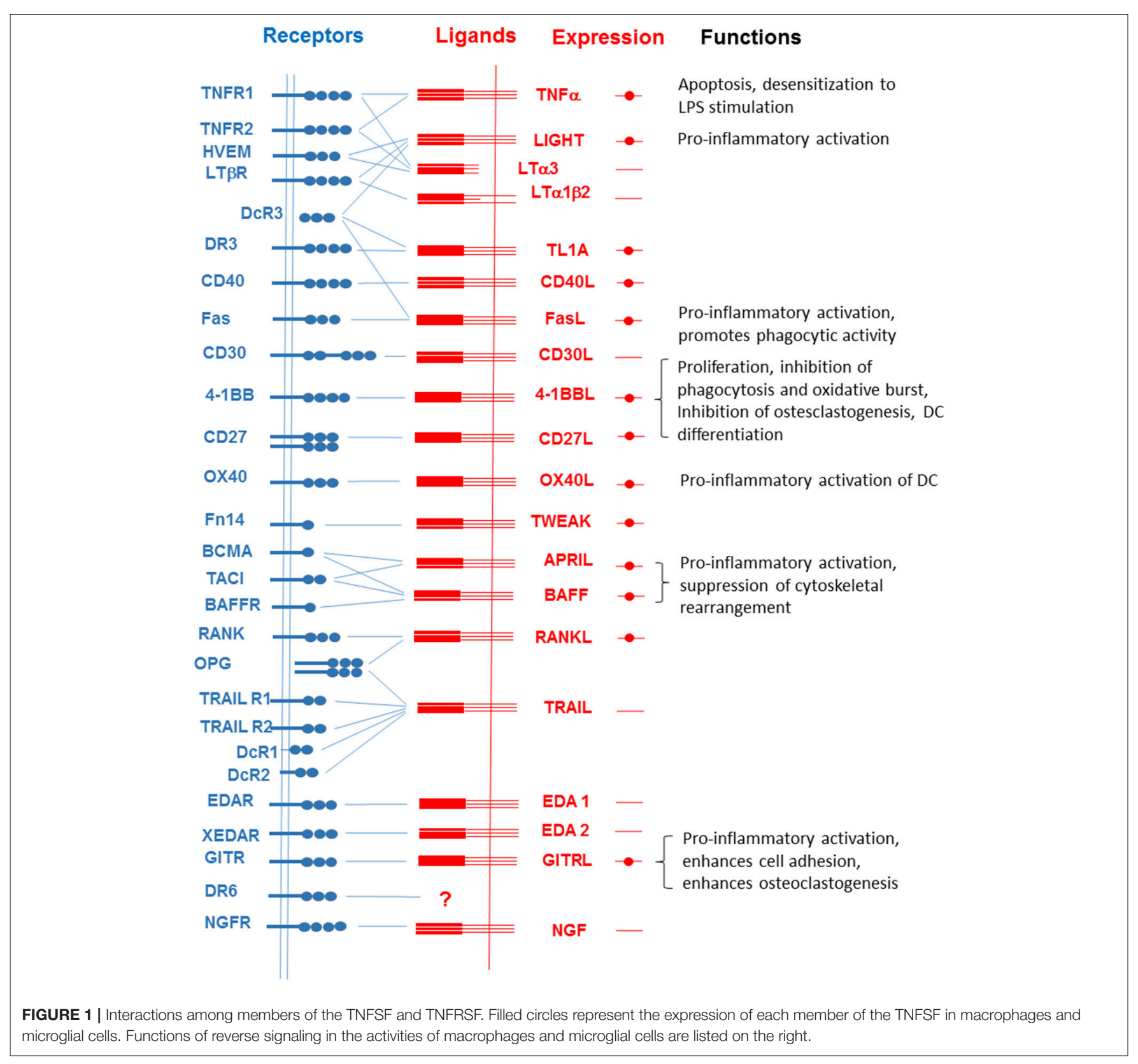

activation. The cellular response is mediated by PI3K/AKT and MAPK/Mitogen- and stress-activated protein kinase 1 (MSK1) pathways, which culminate at the formation of a trimeric complex containing NF- $\kappa \mathrm{B}$, cyclic AMP-response element binding protein (CREB), and CREB binding protein. This trimeric complex is responsible for the synergistic activation of $\mathrm{NF}-\kappa \mathrm{B}$ and, consequently, pro-inflammatory responses of the cell (22). The involvement of ERK in pro-inflammatory activation has been further confirmed in studies showing the existence of crosstalk between BAFF-mediated signaling and signals initiated from immune receptor expressed on myeloid cells 1 (IREM1, CD300F) (23-25). IREM-1 is an immunoreceptor tyrosinebased inhibition motif (ITIM)-containing cell surface molecule that exerts its inhibitory effects through interaction of its ITIMs with $\mathrm{SH} 2$-containing tyrosine phosphatase (SHP)-1. Via its phosphatase activity, SHP-1 suppresses cellular signals associated with PI3K, Janus kinase 2, MAPKs, signal transducers and activators of transcription, and NF-кB $(26,27)$. Simultaneous stimulation of BAFF and IREM-1 results in suppression of BAFFmediated ERK activation owing to IREM-1-mediated activation of SHP-1 (22). These findings indicate that it is necessity to re-evaluate the role of BAFF in diseases in which BAFF is overexpressed in macrophages.

Despite the similarities in their extracellular domains and receptors, BAFF and APRIL have quite different intracellular domains (ICDs; Figure 2). On the other hand, the ICD in 


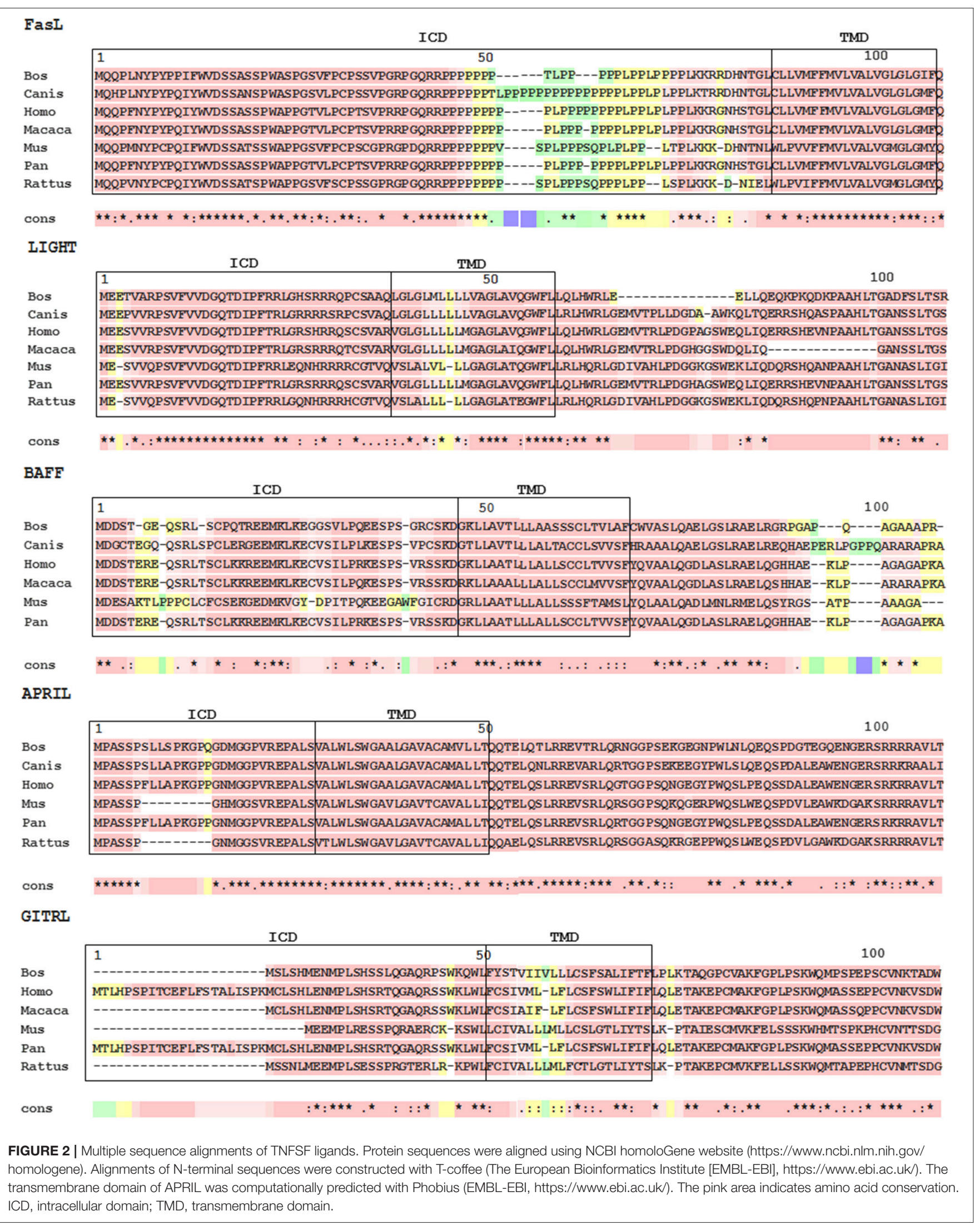


each member is highly conserved in among different species, supporting the importance of their intracellular domains for the generation of reverse signaling.

BAFF/APRIL and their receptor systems are believed to be involved in the pathogenesis of various autoimmune diseases. Accordingly, serum BAFF levels have been shown to be abnormally upregulated in patients with systemic lupus erythematosus (SLE), rheumatoid arthritis (RA), and Sjögren's syndrome (28-31). The mAb-based therapeutic belimumab (LymphoStat-B) was approved by the US Food and Drug Administration for the treatment of SLE in 2011 (32). Belimumab was developed by screening of a phage-display library and consists of two heavy chains and two light chains with specificity against BAFF; this antibody blocks BAFF-mediated activation of its receptors and subsequent cellular activation (33). Although belimumab interacts with soluble BAFF and not with the membrane-bound form of BAFF (34), the antibody may crosslink with and thus activate the membrane boundform of BAFF on cells of monocyte lineage. Another mAbbased therapeutic currently being evaluated in clinical trials is tabalumab (35), an anti-BAFF human mAb that has been reported to neutralize both membrane-bound and soluble forms of BAFF (36). Because tabalumab binds the membranebound form of BAFF, exploring whether this antibody induces reverse signaling from BAFF in various cell types could be beneficial for the future development of agents targeting BAFF or APRIL.

BAFF and its receptors are widely expressed in brain glial cells (Figure 3). Microglia express BAFF, BAFFR, and TACI (37). In contrast, astrocytes and neurons only express BAFF and BAFFR, respectively $(38,39)$. Microglial expression and release of BAFF is increased by ganglioside mixture treatment (37) and brain injury (38). In particular, cerebral ischemia and reperfusion injury enhance microglial BAFF and neuronal BAFFR expression, suggesting important roles of the BAFF/BAFFR interaction in brain injury conditions (38). Neuronal survival was promoted by BAFF/BAFFR ligation under ischemic stress conditions in vitro as well as middle cerebral artery occlusion in vivo. Interactions between microglial BAFF and neuronal BAFFR seem to exert neuroprotective effects in brain ischemia injury and may represent a promising therapeutic target for patients with stroke. BAFF released from microglia has been proposed to act on microglia themselves or B cells infiltrated into the brain to regulate central nervous system (CNS) inflammation (37). A previous study by Krumbholz et al. identified astrocytes as a main cellular source of BAFF in multiple sclerosis plaques, suggesting that BAFF produced by brain astrocytes may be involved in Bcell survival under inflammatory conditions (39). BAFF has also been reported to have a different functional role in experimental autoimmune encephalomyelitis (EAE); specifically, BAFFR genedeficient mice show increased peripheral inflammatory cytokines and higher disease severity compared with wild-type animals, suggesting alteration of macrophage activation and immune responses in the absence of BAFFR (40).

Reverse signaling of BAFF has not been specifically investigated in microglia or other glial cell types. Nevertheless, the wide distribution of BAFF and its receptors in various neural cell types indicates that BAFF/BAFFR signaling may be important for interglial crosstalk or neuron/glia interactions.

APRIL has been shown to be expressed by astrocytes in areas of gliosis and by several glioblastoma cell lines (Figure 3) (41). Under inflammatory conditions, astrocytes act like microglia, producing pro-inflammatory cytokines, chemokines, and nitric oxide. Astrocytic expression of APRIL has been shown to be increased in the brains of patients with multiple sclerosis (41). Thus, APRIL expressed in reactive astrocytes may participate in the regulation of neuro-inflammatory responses and gliotic scar formation in multiple sclerosis and other pathological conditions. Notably, in this previous study, microglia were negative for APRIL expression. However, the role of APRIL in glioblastoma cells is still not clear.

Further evidence of the role of BAFF and APRIL in CNS inflammation was obtained from a marmoset monkey model of multiple sclerosis (42). Indeed, administration of antibodies against either human BAFF or APRIL delayed EAE development via different mechanisms.

\section{LIGHT}

The expression of LIGHT (also known as TNFSF14 or CD258) has been observed in activated $\mathrm{T}$ and B lymphocytes, monocyte/macrophages, granulocytes, natural killer (NK) cells, and DCs (43-46). LIGHT can interact with three types of receptors, i.e., herpes virus entry mediator (HVEM), lymphotoxin $\beta$ receptor (LT $\beta R$ ), and decoy receptor (DcR3) $(43,47)$. HVEM or LT $\beta$ R mediates LIGHT-induced T-cell costimulation and/or subsequent cytokine production (48-52), whereas DcR3, which is a soluble receptor without a TMD, works as a competitive inhibitor of LIGHT-induced cellular responses (43, 47, 53). HVEM (also known as TNFRSF14, LIGHTR, or TR2), which was initially identified as a cellular coreceptor for herpes simplex virus (HSV) entry (54), has a wide tissue distribution, including lymphoid tissues, and is expressed on peripheral blood leukocytes, such as $\mathrm{T}$ and $\mathrm{B}$ lymphocytes and monocytes $(55,56)$. Similar to other members of this receptor superfamily, HVEM stimulation leads to the activation of transcription factors, including NF- $\kappa \mathrm{B}$ and activator protein (AP1) (56). The expression of LT $\beta R$ has been detected on endothelial, epithelial, and myeloid cells (57). LT $\beta$ R functions as a mediator of cancer-associated inflammation $(58,59)$, regulator of lymphoid organ development $(60,61)$ and homeostatic stimulator of DC expansion $(62,63)$. LT $\beta$ R-mediated signaling induces the classical NF- $\kappa$ B pathway via TNF receptor-associated factor $2 / 5$ (TRAF2/5) $(64,65)$ or the non-canonical NF- $\kappa$ B pathway via TRAF3 $(66,67)$. LT $\beta R$ can also interact with and be stimulated by LT $\alpha 1 \beta 2$, which is expressed on the surface of the cell. Because HVEM also interacts with the homotrimer of LT $\alpha$ (LT $\alpha 3)$ (57, 64), there seems to be extensive crosstalk between LIGHT/HVEM and LT/LT receptor systems (Figure 1).

The possibility of LIGHT-mediated reverse signaling has been reported in $\mathrm{T}$ cells, in which stimulation of LIGHT has costimulatory effects; indeed, treatment with anti-LIGHT mAbs enhances responses induced by $\mathrm{T}$-cell receptor ligation. These 


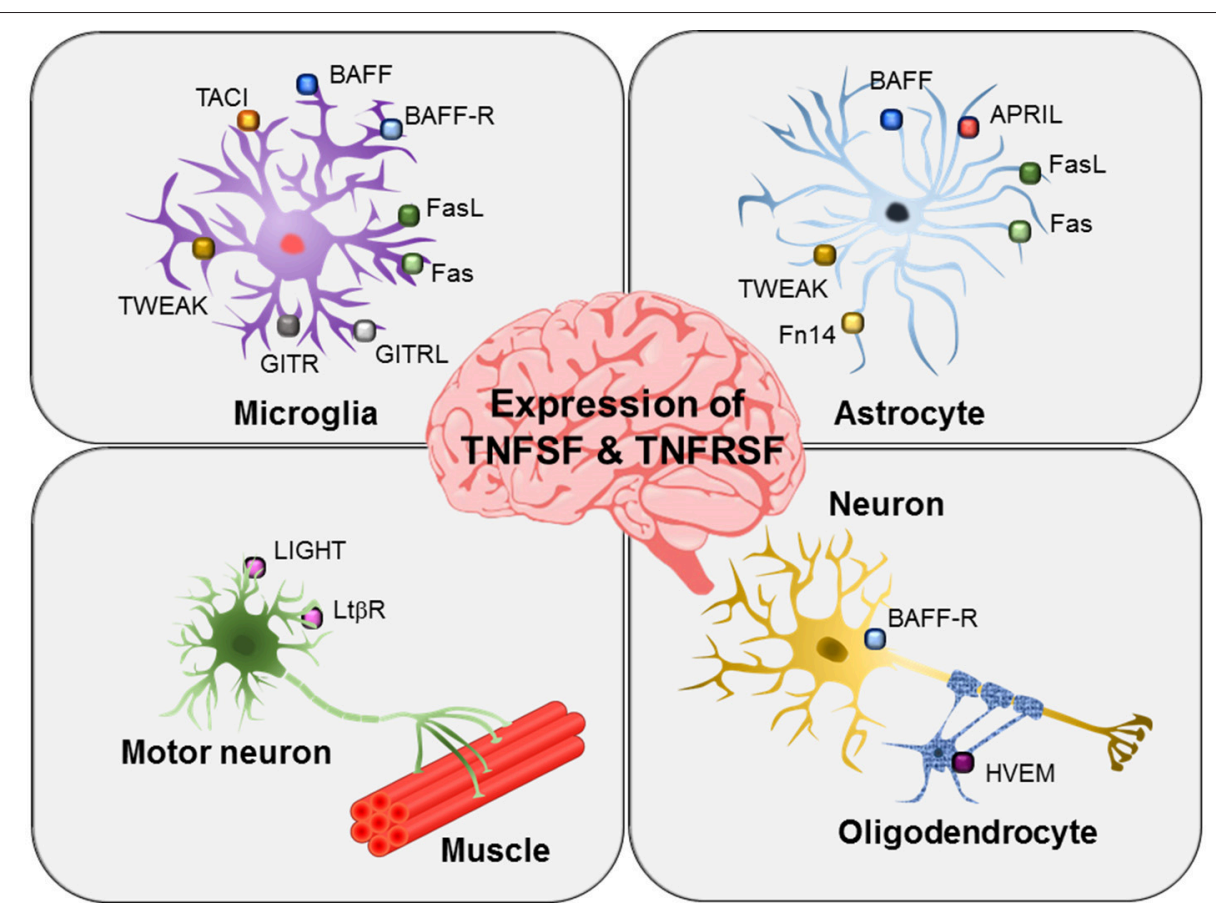

FIGURE 3 | Expression of TNFSF and TNFSRSF members in brain glial cells and neurons. Different members of the TNFSF and TNFSRSF are expressed on microglia, astrocytes, oligodendrocytes, and neurons as indicated. In particular, motor neurons have been shown to express LIGHT and LT $\beta$ R.

responses include cell proliferation, cytokine production, and cytotoxic activity via MAPK activation. Although treatment of mice with DcR3-Fc downregulates graft-vs.-host responses and ameliorates the rejection of mouse heart allografts, it is not clear whether these effects are mediated by direct stimulation of membrane-bound LIGHT or perturbation of LIGHT-induced activation events $(68,69)$. Reverse signaling in macrophage lineage cells was demonstrated when the human macrophagelike cell line THP-1 was treated with a LIGHT-specific agonistic $\mathrm{mAb}$. Cells responded by inducing the expression of pro-inflammatory mediators, such as interleukin (IL)-8 and matrix metalloproteinase (MMP)-9 while suppressing phagocytic activity. The signaling pathway initiated by LIGHT is mediated by the MAPK ERK and by PI3K, leading to activation of the major inflammatory transcription factor NF- $\mathrm{KB}(70)$.

Sequence analysis of the LIGHT ICD indicated a high level of conservation among different species. However, there were no similarities with currently known protein motifs (Figure 2).

LIGHT/HVEM/LT $\beta$ R expression has not been thoroughly investigated in brain microglia or astrocytes. Instead, oligodendrocytes have been shown to express HVEM (71), and motoneurons express LIGHT and LT $\beta$ R (Figure 3) (72). In an amyotrophic lateral sclerosis animal model, interferon (IFN)$\gamma$ secreted from astrocytes was found to induce LIGHT/LT $\beta$ R signaling in motoneurons, thereby stimulating non-cell autonomous neurotoxic pathways (72). Moreover, researchers found that astrocyte/neuron crosstalk contributed to the elimination of motoneurons expressing both LIGHT and LT $\beta$ R under pathological conditions. Microglia may also participate in the non-cell autonomous motoneuron selective death pathways by communicating with astrocytes or motoneurons. The study further suggested that IFN- $\gamma /$ LIGHT/LT $\beta$ R pathways may be useful therapeutic targets in motoneuron disease.

Although less is known about the glial expression of LIGHT/HVEM/LT $\beta$ R, a previous study by Mana et al. investigated the role of LIGHT in CNS inflammation (73). In the EAE model, LIGHT was found to be involved in restraining macrophages and microglia, thereby limiting disease progression and nerve damage. However, further studies are required to elucidate the cell type-specific roles of LIGHT in autoimmune CNS inflammation because only conventional LIGHT-deficient mice have been evaluated.

HVEM expression has been found in oligodendrocytes (71). This study, however, focused on the role of HVEM as a receptor for viral entry during HSV-1 infection in a human oligodendrocytes. They observed the colocalization of HVEM and nectin-1 with HSV-1 particles, implying that HVEM may be a major viral receptor functioning in these cells.

\section{GLUCOCORTICOID-INDUCED TNFR-RELATED PROTEIN (GITR) LIGAND (GITRL)}

GITR (also known as AITR or TNFRSF18) was originally identified in activated T-lymphocytes, functioning as a regulator of T-cell receptor-mediated cell death (74). Later, its expression was detected in regulatory $\mathrm{T}$ cells (Tregs), effector $\mathrm{T}$ cells, 
macrophages, and microglia (75-79). The ligand of GITR (GITRL) is mainly expressed in immature and mature DCs, B cells, endothelial cells, macrophages, and microglia $(75,80$, 81). Forward signaling initiated from GITR acts to costimulate CD25-effector T cells, which respond through proliferation and cytokine production. This GITRL-induced forward signaling is mediated TRAFs and NF- $\mathrm{B}$ (82-85). In human macrophagelike THP-1 cells, ligation of GITR results in the expression of pro-inflammatory mediators via activation of MAPK and PI3K (77). The GITRL/GITR system has also been implicated in various processes, including suppression of $\mathrm{CD} 4{ }^{+} \mathrm{CD} 25^{+}$Tregs, antiviral and antitumoral responses, leukocyte extravasation, RA development, and chronic lung inflammation (79, 86-88).

Reverse signaling through GITRL has been the subject of intense investigations. GITR ${ }^{-/-}$mice show decreased numbers of leukocytes in inflamed areas $(89,90)$, and treatment of experimental animals with GITR-Fc fusion protein ameliorates the symptoms of autoimmune or chronic inflammatory diseases (91). These effects may be due to induction of GITRL-mediated reverse signaling or blockage of GITR signaling (neutralizing GITRL). Additional studies have indicated that both of these mechanisms are possible. Some reports have favored the reverse signaling mechanism. For example, adherence of $\mathrm{GITR}^{-/-}$ murine splenocytes or HL60 human monocytic cells to endothelial cells was found to be enhanced when the cells were treated with the GITR-Fc fusion protein. Moreover, stimulation with GITRL triggers the upregulation of intracellular adhesion molecule (ICAM)-1 and vascular cell adhesion molecule-1 (80). In contrast, other reports have favored the neutralizing effect of the fusion protein. Indeed, analysis of a spinal cord injury model in $\mathrm{GITR}^{-/-}$mice indicated that the GITR-Fc fusion protein failed to alter the disease severity in the knockout mice but decreased disease severity in wild-type mice (92).

Stimulation of murine primary macrophages or human macrophage-like THP-1 cells with GITR-Fc fusion protein or anti-GITRL mAbs induces pro-inflammatory mediators (e.g., MMP-9, IL-8, monocyte chemotactic protein-1, TNF $\alpha$, and IL- $\beta$ ) and upregulates ICAM- 1 expression. GITRL-mediated activation signals were found to be mediated by ERK and NF$\kappa \mathrm{B}$ (93). Treatment of murine monocytic cells with recombinant soluble GITR (rsGITR) in combination with IFN- $\gamma$ results in synergistic induction of inducible nitric oxide (NO) synthase (iNOS), cyclooxygenase (COX)-2, and MMP-9. Analysis of the signaling mechanisms indicated the involvement of tyrosine phosphorylation and NF- $\mathrm{B}$ (94-96).

Both GITR and GITRL are expressed at the same time in some cell types, particularly macrophages and microglial cells (7577). Clusters of macrophages/microglia can be easily observed in lesion areas in atherosclerotic plaques, synovium of patients with RA, and amyloid plaques in Alzheimer's brain. Activation signals initiated from both the receptor and ligand, which can occur within one cell or among adjacent cells, may cause synergistic pro-inflammatory activation.

GITRL-mediated reverse signaling is also involved in osteoclastogenesis. When osteoclast precursors are treated with receptor activator of NF- $\kappa \mathrm{B}$ ligand (RANKL) and macrophage colony-stimulating factor (M-CSF), the expression of both GITR
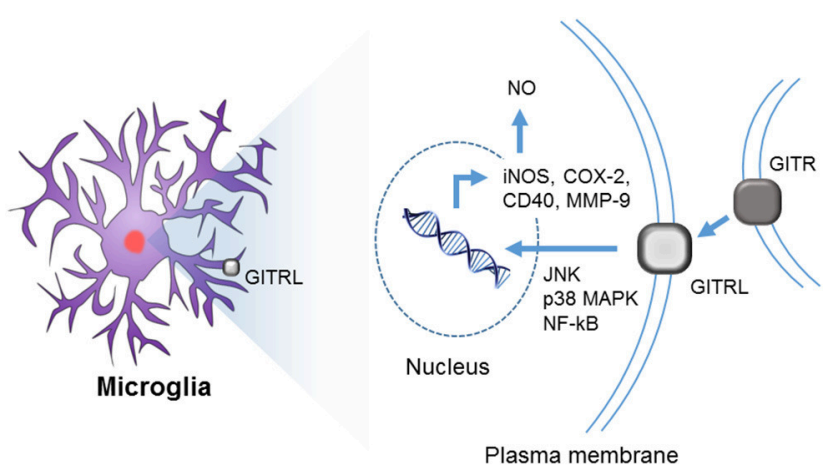

FIGURE 4 | Reverse signaling through GITRL in brain microglia. Although both GITR and GITRL are expressed on microglia, only GITRL participates in the inflammatory activation of microglia. Upon ligation of GITRL, MAPKs (such as JNK and p38) and NF-кB are activated, and consequently, the expression of iNOS, COX-2, CD4O, and MMP-9 genes is induced with concurrent NO production.

and GITRL is induced. Additional treatment with rsGITR enhances osteoclastogenesis, which is blocked by neutralizing anti-GITRL antibodies. This effect is related to rsGITR-induced production of prostaglandin $\mathrm{E}_{2}$ via COX-2. Prostaglandin $\mathrm{E}_{2}$ then downregulates the steady-state level of osteoprotegerin (OPG), which has anti-osteoclastogenic effects (97).

Reverse signaling through GITRL has been well-characterized in microglia (Figures 3, 4). Hwang et al. first reported the expression of both GITR and GITRL in brain microglia and showed that reverse signaling through GITRL in microglia induces inflammatory activation, as determined by $\mathrm{NO}$ production and pro-inflammatory gene expression, such as iNOS, MMP-9, COX-2, and CD40 (Figure 4) (75). Furthermore, they demonstrated that GITRL-mediated microglial activation is executed by canonical inflammatory signaling, such as NF- $\kappa \mathrm{B}$ and MAPK pathways. These results indicate that the GITR/GITRL system, particularly GITRL reverse signaling, may play a regulatory role in microglia-mediated neuroinflammation.

\section{FAS LIGAND (FasL)}

Fas (CD95), a type I transmembrane protein with characteristic cysteine-rich domains, works as a receptor for FasL (CD95L/CD178) (98, 99). Ligation of Fas induces caspasedependent apoptotic cell death through its death domain, which is found in the ICD (100-103). Constitutive expression of Fas has been detected in many cell types, although FasL expression is restricted to $\mathrm{CD}^{+}{ }^{+} \mathrm{T}$ helper cells, activated $\mathrm{CD} 8^{+}$cells, NK cells, and macrophages (104). Developmental stage-dependent expression of Fas during hematopoiesis has also been reported (105). Alternative splicing of Fas mRNA generates seven isoforms, which include soluble forms that can serve as DcRs (106). Activation of T cells leads to upregulation of cell surface expression of FasL, which then interacts with Fas on the same or adjacent cells. This interaction triggers apoptotic cell death, called activation-induced cell death (107). NK cells and $\mathrm{CD}^{+}$ 
cytotoxic $\mathrm{T}$ lymphocytes use Fas/FasL interaction as one of the two main pathways that are responsible for their cytotoxic effector functions (108). Cells in immune-privileged sites and some tumor cells constitutively express FasL for the suppression of immune responses against them $(109,110)$.

In addition to its apoptosis-inducing properties during tissue injury and organ dysfunction (111-113), Fas also works as an enhancer of pro-inflammatory responses $(114,115)$ though caspase-independent and myeloid differentiation factor 88 (MyD88)-dependent signaling pathways (116-118). MyD88 serves as cross point for the crosstalk between the Fas-mediated signaling pathway and IL-1R1 and/or TLR4-mediated signaling pathways (119). Fas also enhances the proliferation of fibroblasts and $\mathrm{T}$ cells (120-122), which are involved in caspase activation without cell death (123-126). In THP-1 cells, treatment with anti-Fas mAbs or incubation with FasL-expressing cells results in pro-inflammatory activation of these cells through activation of ERK and NF- $\kappa B$ (127). These reports indicate that Fas-mediated signaling pathways are under complex regulation and provoke various responses in different cell types.

Unlike other members of the TNFSF, FasL has a long ICD containing around 80 amino acids with a high level of conservation across different mammalian species. The ICD of Fas contains two casein kinase I (CKI) binding sites and a prolinerich region that contains multiple binding sites for the $\mathrm{SH} 3$ domain (2). The CKI phosphorylation motif can be found in five other members of the TNFSF and is required for the FasLmediated activation of nuclear factor of activated T cells (NFAT) and costimulation of T cells (104) (128). Possible interactions of this ICD with SH3-containing signaling adapters, such as Grb2, Fyn, and PI3K, have been reported $(129,130)$. The proline-rich sequence is also required for the storage of FasL in specialized secretory vesicles and the translocation of FasL to the plasma membrane upon activation (131). This intracellular localization appears to be regulated by the interaction of the proline-rich region with the SH3-containing adapter protein PSTPIP, which further interacts with the tyrosine phosphatase PTP-PEST (132).

Reverse signaling initiated from FasL, particularly via its proline-rich sequence, is involved in costimulation of $\mathrm{CD}^{+}$ $\mathrm{T}$ cells, optimal thymocyte maturation, and antigen-driven proliferation of mature $\mathrm{T}$ cells (133-138). Upon activation, increasing fractions of FasL have been reported to be localized in lipid rafts, sphingolipid- and cholesterol-enriched dynamic membrane microdomains required for some of signaling and trafficking processes $(133,139)$. Along with increased localization in lipid rafts, activated FasL associates with SH3containing proteins. The proline-rich domain is required for phosphorylation of FasL itself and other signaling molecules, including AKT, ERK, and c-Jun N-terminal kinase (JNK). These signaling events then activate transcription factors (NFAT and AP-1) and enhance IFN $-\gamma$ production $(1,128,133)$. Interestingly, FasL with an alteration in the proline-rich region (deletion of amino acids 45-54) abolishes its costimulation activity without affecting its death-inducing activity, indicating the separation of functional domains for different functions (128).

Although various functions of FasL have been welldocumented in $\mathrm{T}$ cells, its roles in other cell types have not been extensively investigated. In breast cancer cell lines, IFN- $\gamma$ treatment induces the translocation of pre-existing FasL to the cell membrane, and treatment with Fas-Fc fusion protein induces apoptotic cell death (140). In the human macrophage-like cell line THP-1, treatment with either antiFasL mAbs or Fas-Fc fusion protein induces the production of pro-inflammatory mediators (e.g., MMP-9, TNF- $\alpha$, and IL-8) and promotes phagocytic activity. This pro-inflammatory activation is mediated by MAPKs and NF- $\kappa$ B. In addition, FasL-mediated inflammatory activation is blocked by triggering of IREM-1 (141).

Fas and FasL are expressed in both microglia and astrocytes (Figure 3). As recently reviewed by Jha et al., microglia/astrocyte crosstalk constitutes an important component of neural cell communication, orchestrating a range of physiological and pathological processes in the CNS, such as brain development and neurological dysfunction (142). The bi-directional communication between microglia and astrocytes is mediated by either secreted or cell surface proteins. Fas/FasL expressed in microglia and astrocytes may mediate such crosstalk. Moreover, a previous study by Badie et al. suggested a role of the Fas/FasL interaction in microglia/glioma crosstalk (143). The authors reported that expression of the membrane-bound form of FasL is increased in the glioma environment and that FasL-expressing microglia may contribute to the local immunosuppressive environment of malignant glioma. However, the precise role of microglia in glioma biology remains unclear.

Fas is expressed at low levels and is upregulated upon TNF$\alpha$ or IFN- $\gamma$ treatment in primary mouse microglia cultures (144, 145). Moreover, Fas is expressed constitutively on astrocytes and is upregulated by treatment with IL- 1 , IL- 6 , or TNF- $\alpha$. FasL is expressed on fetal and adult astrocytes and on microglia (144, 145). Thus, glial Fas/FasL may have a role in the induction of apoptosis in the CNS (144). Interestingly, however, the Fas/FasL interaction results in different signals in microglia vs. astrocytes. For example, Fas mediates cell death signaling in microglia, but transmits an inflammatory signal in astrocytes (145). Wang et al. have reported that astrocytic FasL mediates the elimination of autoimmune $\mathrm{T}$ cells in the CNS, contributing to recovery from EAE (146). This regulatory role of FasL expressed in astrocytes was demonstrated using glial fibrillary acidic protein/Cre FasL (fl/fl) mice in which the FasL gene was selectively deleted in astrocytes. In contrast, a study by Okuda et al. showed a tissue destructive role of FasL in the acute phase of EAE (147). When neutralizing antibodies against FasL were injected intrathecally, the disease severity was attenuated, and neuroinflammation and myelin damage were reduced in the CNS.

\section{TNF-LIKE WEAK INDUCER OF APOPTOSIS (TWEAK)}

As a member of TNFRSF, fibroblast growth factor-inducible 14 (FN14) is expressed in various cell types, including lymphocytes, macrophages, endothelial cells, fibroblasts, and keratinocytes, particularly under conditions, such as inflammation and malignancy. Its ligand, TWEAK, is expressed in lymphocytes, 
macrophages, NK cells, renal tubular epithelial cells, and glomerular mesangial cells (148-150). Interestingly, both TWEAK and FN14 are widely distributed among many tissue types after exposure to inflammation (151). As a result, the TWEAK/FN14 system has been shown to be involved in inflammation, angiogenesis, cell proliferation, and apoptosis and in various diseases, including SLE, renal damage, RA, cancer, and conditions associated with cutaneous inflammation (152-154). FN14-mediated forward signaling leads to NF- $\kappa$ B activation $(155,156)$.

TWEAK-mediated reverse signaling has not been reported. However, a naturally occurring fusion protein between the ICD of TWEAK and the receptor binding domain of APRIL, called TWE-PRIL (157-159), has been reported. Analysis of APRIL ${ }^{-/}$mice (which lack APRIL and TWEPRIL) demonstrated the involvement of TWE-PRIL reverse signaling in suppression of sympathetic axon growth and tissue innervation (160).

TWEAK mRNA expression has been detected in both microglia and astrocytes (161). FN14 expression has been reported in astrocytes; however, its expression has not been detected in brain microglia. The TWEAK/FN14 interaction has been implicated in CNS inflammation. Proliferation of FN14-expressing astrocytes is increased upon exposure to recombinant TWEAK protein. Moreover, TWEAK mRNA expression is enhanced in spinal cords during EAE, and disease severity is increased in transgenic mice overexpressing TWEAK. These results indicate that the TWEAK/Fn14 interaction in spinal glia is involved in CNS autoimmune inflammatory responses and can be targeted for EAE and MS therapy. Consistent with this, treatment of cultured human astrocytes with TWEAK increases ICAM expression and IL-6/IL-8 secretion, inducing reactive astrocyte-like characteristics (162). TWEAK also induces C-C motif chemokine ligand 2 (CCL2) release from astrocytes and endothelial cells in culture. Blockade of TWEAK/FN14 signaling inhibits TWEAK-induced CCL2 production and ameliorates EAE (163). Furthermore, administration of anti-TWEAK neutralizing antibodies reduces leukocyte infiltration and disease severity in EAE animals (164). These results are consistent with the pro-inflammatory and disease-promoting effects of TWEAK in CNS inflammation.

\section{CD137L (4-1BBL)}

CD137 (4-1BB), originally identified as a T-cell costimulatory molecule, is expressed in activated T cells, B cells, NK cells, neutrophils, macrophages, and DCs and functions to promote their effector functions (165-167). The ligand of CD137 (CD137L, 4-1BBL) was found to be expressed in B cells, macrophages, and DCs $(168,169)$. Although CD137- or CD137Lknockout mice show no severe defects, they have a higher sensitivity to viral infection (170). Treatment with agonistic anti-CD137 antibodies or CD137L-Fc fusion protein results in expansion of tumor-specific T cells and ameliorates experimental autoimmune encephalomyelitis through modulation of the balance between Th17 and Tregs $(171,172)$.

For CD137L-mediated reverse signaling, most studies have been conducted using monocytes/macrophages. Stimulation of peripheral blood monocytes or bone marrow-derived macrophages with anti-CD137L mAbs or CD137-Fc fusion protein triggers a robust proliferative response, enhances cell adhesion, and/or stimulates pro-inflammatory activation associated with phosphotyrosine-mediated signaling $(173,174)$. This proliferation-inducing effect of CD137L has been reported to be mediated by the AKT/mammalian target of rapamycin (mTOR) pathway, resulting in reprogramming of glucose metabolism in a way that supports energy demand and biomass production. CD137L stimulation increases glucose uptake and upregulates enzymes involved in glucose transport/lysis and lactate production. Expression of genes involved in the pentose phosphate pathway and lipogenesis is also enhanced (175).

Bone marrow macrophages can be differentiated into osteoclasts by M-CSF and RANKL treatment. This osteoclastogenic process is inhibited by additional treatment with immobilized CD137L-Fc fusion protein or recombinant CD137 (176). Various experiments investigating this reverse signaling pathway have indicated that the signaling pathway is mediated by MAPKs, AKT, mTOR, PI3K, PKA, C/EBP, and CREB, resulting in induction of IL-6 and TNF expression (174, 177-179). Recombinant CD137 treatment also inhibits phagocytosis and oxidative burst (180). Interestingly, the extracellular domain of CD137L has been reported to directly interact with TNFR1, and this interaction appears to be required for CD137L-mediated reverse signaling. As a consequence, treatment of monocytes with TNF augments CD137-induced IL-8 expression, and inhibition of TNFR1 using TNFR1-neutralizing antibodies results in inhibition of CD137L-mediated responses, such as cell adhesion, apoptosis, CD14 expression, and IL-8 production (181). Using a two-hybrid system in a mouse macrophages, a novel transmembrane protein TMEM126A was found to interact with CD137L, and knockdown of TMEM126A was shown to abolish CD137L-mediated induction of tyrosine phosphorylation and pro-inflammatory cytokines (182). These results suggested the complex nature of CD137L-mediated reverse signaling. Further studies are needed to fully elucidate these mechanisms.

CD137L-mediated reverse signaling enhances DC maturation and potentiates the ability of DCs to stimulate T cells (180, 183). In contrast, a recent report showed that blockade of CD137L-mediated reverse signaling resulted in promotion of intratumoral differentiation of $\mathrm{IL}-12$-producing $\mathrm{CD}_{103}{ }^{+} \mathrm{DCs}$ and type 1 tumor-associated macrophages, which are required for the generation of IFN- $\gamma$-producing CD ${ }^{+}$T cells (184).

Most recently, CD137-CD137L signaling has been implicated in the hypothalamic interglial crosstalk under obese conditions (185). Mice fed with high-fat diet (HFD) showed an enhanced expression of CD137 and CD137L in the brain hypothalamus (186). Treatment of cultured glial cells with obesity-related molecules including free fatty acid and glucose promoted the expression of CD137 in astrocytes and CD137L in microglia, respectively (186). While forward signaling through CD137 
in astrocytes increased their reactivity, reverse signaling through CD137L in microglia augmented the secretion of proinflammatory mediators, such as MCP-1. These recent findings suggest that CD137-CD137L signaling mediates microglia-astrocyte crosstalk in hypothalamic inflammatory responses under obese conditions, and CD137L reverse signaling in microglia might be a potential therapeutic target for the suppression of obesity-induced hypothalamic inflammation and related metabolic diseases.

\section{REVERSE SIGNALING INITIATED FROM OTHER TNFSF MEMBERS}

The list of TNSF members that can induce reverse signaling is increasing as more studies focus on this aspect of the TNFSF/TNFRSF system. In the case of TNF, its ICD contains a nuclear localization signal sequence that can be liberated upon stimulation of the membrane-bound form of TNF (mTNF) with anti-TNF antibodies. This cleaved $10-\mathrm{kD}$ fragment containing the ICD and TMD were found to be localized to internal membranes and nuclear fractions (187). Stimulation of mTNF with soluble TNFR increases intracellular calcium levels in RAW264.7 mouse monocytes (188). Additionally, soluble TNFR treatment causes changes in mTNF phosphorylation status, and casein kinase, which can phosphorylate the serine residues in the ICD of mTNF, has been implicated in this reverse signaling mechanism (188-190).

In monocyte/macrophage lineage cells, stimulation of mTNF with mAbs or soluble receptors leads to activation of MAPKs, particularly ERK, and the cells have been shown to be resistant to subsequent stimulation with LPS $(191,192)$. Other investigators have shown that stimulation of mTNF with anti-TNF antibodies results in internalization of the mTNF/anti-TNF complex into early endosomes and then lysosomes in macrophages and DCs (193). In addition, stimulation of synovial macrophages in RA joints with chimeric anti-TNF mAbs (infliximab) or soluble TNFR (etanercept) results in the induction of caspaseindependent apoptotic cell death (194-196).

Some members of the TNFSF/TNFRSF show major crosstalk among ligand/receptor pairs. For example, DcR3, which is the counterpart of LIGHT, TNF-like ligand 1A (TL1A), and FasL, contains three conserved cysteine-rich domains characteristic of a TNFR (47, 197-199). Originally, DcR3 was thought to neutralize these members of the TNFSF through competition with their receptors. However, treatment of DCs with DcR3 modulates the differentiation and activation of DCs, which then directs naïve $\mathrm{T}$ cells to differentiate into a Th2 phenotype (200). In addition, monocytes and THP-1 cells respond to DcR3 treatment with induction of actin reorganization and enhancement of adhesion. Analysis of this reverse signaling revealed the involvement of protein kinase $\mathrm{C}$ (PKC), PI3K, focal adhesion kinase, and Src kinases (69). Additionally, the involvement of DcR3 in osteoclast development was also reported. When cells of monocyte/macrophage lineage were treated with DcR3, osteoclastogenesis was induced through MAPK signaling and TNF- $\alpha$ expression. These responses enhanced the development of osteoclast phenotypes, such as polynuclear giant morphology, bone resorption, and expression of tartrate-resistant acid phosphatase, CD51/61, and MMP-9 (201).

Of the three counterparts (LIGHT, TL1A, and FasL) of DcR3, reverse signaling has been reported for LIGHT and FasL, but not in TL1A. To date, there is no direct evidence supporting the generation of reverse signaling from TL1A. However, the expression of full-length TL1A has been shown to be correlated with the senescence of endothelial cells, and knockdown of TL1A expression has been shown to reverse the senescence phenotype (202). In a murine colitis model, cell surface expression levels of TL1A were found to be related to the suppressive activity of Tregs in a DR3-dependent manner, suggesting that the strength of signaling initiated from TL1A closely regulates Treg activity (203).

OX40 (CD134) is mainly expressed in activated T cells and acts as a costimulatory molecule for receiving activation and survival signals (204-206). The ligand of OX40 (OX40L) is mainly expressed in $\mathrm{T}$ and $\mathrm{B}$ cells, activated macrophages and DCs, and endothelial cells (207-209). The OX40/OX40L system has been implicated in T-cell costimulation, Treg generation, cell adhesion, and extravasation of T cells (210-214).

When B cells are co-incubated with OX40-expressing $\mathrm{T}$ cells or stimulated with soluble OX40, OX40L-mediated reverse signaling is induced, and the $\mathrm{B}$ cells undergo terminal differentiation into plasma cells. Because $\mathrm{T}$ cells are also activated through this interaction, the OX40/OX40L interaction appears to induce bidirectional signaling events $(215,216)$. A recent analysis of OX40L expression levels in B cells from patients with allergic rhinitis indicated that OX40L expression is positively correlated with allergic markers, such as serum levels of IgE and IL-4 (217).

In freshly isolated human blood DCs, mAb-mediated crosslinking of OX40L enhances CD40L-mediated expression of IL-12. In DCs derived from monocytes with IL-4 and granulocyte-macrophage CSF treatment, ligation of OX40L enhances the production of pro-inflammatory cytokines (e.g., TNF- $\alpha$, IL-12 p40, IL-1 $\beta$, and IL-6) and the expression of DC activation markers (e.g., CD83, CD80, CD86, CD54, and CD40) (218). Although the signaling pathway has not been elucidated, these data clearly support the role of OX40L-mediated reverse signaling in DC activation and maturation.

As a ligand of CD40, CD40L (CD154, gp39) is expressed in and activates T cells, B cells, DCs, macrophages, smooth muscle cells, endothelial cells, and platelets. CD40 expression has been detected in B cells, monocyte/macrophages, DCs, mast cells, fibroblasts, and endothelial cells (219-221). The CD40/CD40L system is important for activation of $\mathrm{B}$ cells and subsequent differentiation of these cells into plasma cells and stimulation of immunoglobulin class switching. In addition, this system is also involved in T-cell priming, $\mathrm{T}$ cell-mediated effector functions, macrophage/NK cell/endothelial cell activation, organ-specific autoimmune diseases, graft rejection, and atherosclerosis (222-225).

CD40L-mediated reverse signaling has been studied in CD40knockout mice, in which defective germinal center development 
and antibody production were restored by soluble CD40 treatment. Additionally, reverse signaling was also found to be required for acquisition of B-cell activating potential (226). Although its ICD is only 22 amino acids, this region is highly conserved across various species and generates signaling through Lck, Rac1, MAPKs, and PKC in T cells (227-229). The presence of CD40 and CD40L in lipid rafts has also been reported and could explain the ability of these proteins to generate signaling $(230,231)$.

The expression of RANK has been detected mainly in osteoclasts and their precursors, DCs, and activated T and B cells. In addition, RANK expression has also been detected in a wide variety of tissues. The ligand of RANK (RANKL, also known as TRANCE) has been detected at osteoblasts, $\mathrm{T}$ cells, and stromal cells (232). The interactions between RANK and RANKL can be regulated by the decoy receptor OPG, which has affinity for both RANKL and TNF-related apoptosis-inducing ligand $(233,234)$. The RANK/RANKL/OPG system is involved in osteoclast differentiation/activation, bone remodeling, immune cell function, lymph node development, thermal regulation, and mammary gland development (235-238).

A few reports have provided evidence of RANKL-mediated reverse signaling. The expression of both RANK and RANKL has been detected in B chronic lymphocytic leukemia cells. Treatment of these cells with RANK-Fc fusion protein, but not with RANKL-Fc fusion protein, results in potent enhancement of IL-8 expression (239). Additionally, immobilization of RANKFc fusion protein augments IFN- $\gamma$ secretion by Th1 cells in a p38 MAPK-dependent manner. Addition of RANK-Fc fusion protein during coculture of Th1 cells with antigen-presenting cells results in suppression of IFN- $\gamma$ expression from Th1 cells, probably by blocking the interaction between RANK and RANKL (240). Moreover, osteoblasts, which express RANKL, regulate the differentiation and activation of osteoclasts and their precursors through the interactions of RANK and RANKL. Recent reports, however, have shown that reverse signaling initiated from RANKL is also possible. Soluble RANK treatment enhances p38-mediated mineralization of osteoblasts, which is abolished by knockdown of RANKL. When co-incubated with osteoclasts, osteoblasts respond by increasing p38 MAPK phosphorylation levels, and this response is blocked by abundant soluble RANKL (241).

CD30 is expressed in activated T and B cells and is a clinical marker for Hodgkin's lymphoma and related malignancies (242, 243). Interestingly, crosslinking of surface CD30 can activate latent human immunodeficiency virus in $\mathrm{T}$ cells $(244,245)$. CD30-mediated signaling has costimulatory effects in $\mathrm{T}$ and $\mathrm{B}$ cells, and serum levels of soluble CD30 serve as a prognostic marker of Hodgkin's disease and acquired immunodeficiency syndrome (246-248). The ligand of CD30 (CD30L, CD153) is expressed in activated $\mathrm{T}$ cells, $\mathrm{B}$ cells, and neutrophils. When peripheral blood neutrophils were stimulated with CD30Lspecific mAbs or CD30-Fc fusion protein, cells responded by IL-8 production and oxidative burst. Peripheral blood T cells also responded to anti-CD3 and anti-CD30L antibody cotreatment by increasing metabolic activity, proliferation, and IL-6 production (249). According to a recent report, $\operatorname{IgD}^{+}$
$\operatorname{IgM}^{+} \mathrm{B}$ cells express CD30L after activation with CD40L, IL4 , and specific antigen. Additional treatment with anti-CD30L antibodies or CD30-Fc fusion protein inhibits CD40-mediated signaling through TRAF2 and NF- $\kappa \mathrm{B}$, which results in reductions in class switch DNA recombination and subsequent production of IgG, IgA, and IgE (250).

The expression of CD27L (the ligand of CD27, CD70) has been detected in T cells, B cells, and NK cells. CD27 serves as a T-cell costimulatory molecule that enhances $\mathrm{T}$-cell receptormediated signaling, proliferation, differentiation, and effector functions. The ligand of CD27 (CD27L, CD70) can be detected in lymphocytes, NK cells, and subsets of DCs (251-255). There have been numerous reports on the role of CD27-mediated forward signaling in the activation of T cells, B cells, and NK cells; however, few reports have demonstrated the existence of CD27Lmediated reverse signaling. In a study that explored the immune surveillance function of NK cells in cancer, B cells expressing cytoplasmic deletion mutant of CD27 were implanted in a B-cell acute lymphoblastic leukemia xenotransplant model. Expression of a truncation mutant in malignant cells increased the number of tumor-infiltrating IFN- $\gamma$-producing NK cells. Further analysis indicated that signaling mediated by CD70 on NK cells was transduced by AKT signaling and enhanced the survival and effector function of NK cells (256). In an earlier investigation, a subset of leukemic B cells was found to express CD27L, and stimulation with this ligand using specific mAbs resulted in enhanced cell proliferation. Furthermore, the proliferative response was synergistically enhanced by CD40 ligation (257).

\section{FUTURE PERSPECTIVES}

Although many studies have demonstrated the existence of reverse signaling initiated from TNFSF, it is still unclear how such signals are actually generated. The main reason for this is the short ICDs of these molecules, which usually lack any known signaling motifs. One exception is FasL, which contains several known protein motifs that can interact with multiple signaling adaptors. Although most members of TNFSF has short ICDs with lack of known signaling motifs, the high level conservation of ICD among various mammalian species and its uniqueness in each members of the TNFSF supports that these ICDs are involved in signal generation through yet unidentified mechanism. Bidirectional activation and possible crosstalk among signaling generated from these molecules are expected to generate a complex signaling network that regulates macrophage activity. Further studies are needed to explore this aspect of macrophage regulation.

Many antibody-based therapeutic approaches target the ligand part of TNFSF/TNFRSF system and aim for the blocking of receptor-mediated forward signaling. Some of these agents were proven to be effective for blocking the interaction between cognate ligand and receptor and thus the induction of forward signaling, which manifested in the alleviation of the severity of target disease(s). However, agents targeting the ligand itself or mimicking soluble receptor have the risk of activating membrane-bound form of ligands and, subsequently, generate 
the reverse signaling. These unwanted effects may degrade the therapeutic potential of the agents and may be able to explain some of the side effects observed during clinical trials. Additionally, it is also possible to develop agents that aim for the blockage of reverse signaling in the future.

Finally, the roles of the TNFSF/TNFRSF in CNS inflammation are complex and can be pro-inflammatory or anti-inflammatory depending on the context. Different members of the TNFSF and their receptors are expressed in distinct types of brain glial cells and neurons and exert context-dependent effects on neuroinflammation. Because the expression of these TNFSF members is dynamically regulated under a diverse CNS milieu, their functional roles may be modulated accordingly, with spatiotemporal regulation of the crosstalk of different TNFSF/TNFRSF members. Given the critical role of these TNFSF/TNFRSF members in regulating neuroinflammation, TNFSF/TNFRSF members and related signaling pathways can be potential drug targets for the control of neuroinflammation and the treatment of related diseases in the CNS. However, the benefits and challenges of such an approach must be weighed carefully given the multiple cell-cell interactions that might be affected. Compared with forward signaling of the TNFRSF, little is known about the reverse signaling through the TNFSF. Thus, further studies are needed to better understand reverse signaling pathways in brain glial cells and to determine the therapeutic applications of these pathways in the field of CNS inflammation. Finally, targeting forward and reverse signaling may have its own

\section{REFERENCES}

1. Sun M, Fink PJ. A new class of reverse signaling costimulators belongs to the TNF family. J Immunol. (2007) 179:4307-12. doi: 10.4049/jimmunol.179.7.4307

2. Juhasz K, Buzas K, Duda E. Importance of reverse signaling of the TNF superfamily in immune regulation. Expert Rev Clin Immunol. (2013) 9:33548. doi: $10.1586 /$ eci.13.14

3. Yang QQ, Zhou JW. Neuroinflammation in the central nervous system: symphony of glial cells. Glia (2018). doi: 10.1002/glia.23571. [Epub ahead of print].

4. Lee SH, Suk K. Kinase-based taming of brain microglia toward disease-modifying therapy. Front Cell Neurosci. (2018) 12:474. doi: 10.3389/fncel.2018.00474

5. Lee SH, Suk K. Emerging roles of protein kinases in microgliamediated neuroinflammation. Biochem Pharmacol. (2017) 146:1-9. doi: 10.1016/j.bcp.2017.06.137

6. Song GJ, Suk K. Pharmacological modulation of functional phenotypes of microglia in neurodegenerative diseases. Front Aging Neurosci. (2017) 9:139. doi: 10.3389/fnagi.2017.00139

7. Gorelik L, Gilbride K, Dobles M, Kalled SL, Zandman D, Scott ML. Normal B cell homeostasis requires B cell activation factor production by radiation-resistant cells. J Exp Med. (2003) 198:937-45. doi: 10.1084/jem. 20030789

8. Ng LG, Mackay CR, Mackay F. The BAFF/APRIL system: life beyond B lymphocytes. Mol Immunol. (2005) 42:763-72. doi: 10.1016/j.molimm.2004.06.041

9. Dillon SR, Gross JA, Ansell SM, Novak AJ. An APRIL to remember: novel TNF ligands as therapeutic targets. Nat Rev Drug Discov. (2006) 5:235-46. doi: $10.1038 / \operatorname{nrd} 1982$

10. Schneider P. The role of APRIL and BAFF in lymphocyte activation. Curr Opin Immunol. (2005) 17:282-9. doi: 10.1016/j.coi.2005.04.005 advantages and disadvantages depending on specific TNFSF and TNFRSF members; therefore, a combination of both is likely to be useful in the clinical settings.

\section{AUTHOR CONTRIBUTIONS}

All authors have made a substantial intellectual contribution to this work and approved submission of the manuscript. $\mathrm{W}$-HL and KS formulated the focus of the review. DS and S-GL conducted the literature review and participated in the discussion. W-HL and KS wrote the manuscript.

\section{FUNDING}

W-HL was supported by the Basic Science Research Program through the National Research Foundation of Korea (NRF) funded by the Ministry of Education, Science, and Technology (grant no. 2017R1D1A1B04028358). KS was supported by Basic Science Research Program through the NRF, which is funded by the Korean government (MSIP; grant nos. 2018R1A2A1A05077118, 2016M3C7A1904148, and NRF-2017R1A5A2015391).

\section{ACKNOWLEDGMENTS}

We apologize to those authors whose works are not cited owing to space constraints.

11. Mackay F, Schneider P, Rennert P, Browning J. BAFF AND APRIL: a tutorial on B cell survival. Annu Rev Immunol. (2003) 21:231-64. doi: 10.1146/annurev.immunol.21.120601.141152

12. Lenert A, Lenert P. Current and emerging treatment options for ANCA-associated vasculitis: potential role of belimumab and other BAFF/APRIL targeting agents. Drug Des Devel Ther. (2015) 9:333-47. doi: 10.2147/DDDT.S67264

13. Frieri M, Heuser W, Bliss J. Efficacy of novel monoclonal antibody belimumab in the treatment of lupus nephritis. J Pharmacol Pharmacother. (2015) 6:71-6. doi: 10.4103/0976-500X.155482

14. Treml JF, Hao Y, Stadanlick JE, Cancro MP. The BLyS family: toward a molecular understanding of B cell homeostasis. Cell Biochem Biophys. (2009) 53:1-16. doi: 10.1007/s12013-008-9036-1

15. Hahne M, Kataoka T, Schroter M, Hofmann K, Irmler M, Bodmer JL, et al. APRIL, a new ligand of the tumor necrosis factor family, stimulates tumor cell growth. J Exp Med. (1998) 188:1185-90. doi: 10.1084/jem.188.6.1185

16. Kelly K, Manos E, Jensen G, Nadauld L, Jones DA. APRIL/TRDL-1, a tumor necrosis factor-like ligand, stimulates cell death. Cancer Res. (2000) 60:1021-7.

17. Shu HB, Hu WH, Johnson H. TALL-1 is a novel member of the TNF family that is down-regulated by mitogens. J Leuk Biol. (1999) 65:680-3. doi: 10.1002/jlb.65.5.680

18. Jeon ST, Kim WJ, Lee SM, Lee MY, Park SB, Lee SH, et al. Reverse signaling through BAFF differentially regulates the expression of inflammatory mediators and cytoskeletal movements in THP-1 cells. Immunol Cell Biol. (2010) 88:148-56. doi: 10.1038/icb.2009.75

19. Lee SM, Jeon ST, Kim WJ, Suk K, Lee WH. Macrophages express membrane bound form of APRIL that can generate immunomodulatory signals. Immunology (2010) 131:350-6. doi: 10.1111/j.1365-2567.2010. 03306.x

20. Lee SM, Kim EJ, Suk K, Lee WH. BAFF and APRIL induce inflammatory activation of THP-1 cells through interaction with their conventional 
receptors and activation of MAPK and NF-kappaB. Inflamm Res. (2011) 60:807-15. doi: 10.1007/s00011-011-0336-3

21. Lee SM, Kim WJ, Suk K, Lee WH. Cell to cell interaction can activate membrane-bound APRIL which are expressed on inflammatory macrophages. Immune Netw. (2010) 10:173-80. doi: $10.4110 /$ in.2010.10.5.173

22. Lim SG, Kim JK, Suk K, Lee WH. Crosstalk between signals initiated from TLR4 and cell surface BAFF results in synergistic induction of proinflammatory mediators in THP-1 cells. Sci Rep. (2017) 7:45826. doi: 10.1038/srep45826

23. Izawa K, Kitaura J, Yamanishi Y, Matsuoka T, Kaitani A, Sugiuchi M, et al. An activating and inhibitory signal from an inhibitory receptor LMIR3/CLM-1: LMIR3 augments lipopolysaccharide response through association with FcRgamma in mast cells. J Immunol. (2009) 183:925-36. doi: 10.4049/jimmunol.0900552

24. Lee SM, Nam YP, Suk K, Lee WH. IREM-1 inhibits BAFF-mediated inflammatory regulation of THP-1 cells through modulation of the activities of ERK. Clin Exp Immunol. (2010) 161:504-11. doi: 10.1111/j.1365-2249.2010.04211.x

25. Xi H, Katschke KJ, Jr., Helmy KY, Wark PA, Kljavin N, Clark H, et al. Negative regulation of autoimmune demyelination by the inhibitory receptor CLM-1. J Exp Med. (2010) 207:7-16, S11-5. doi: 10.1084/jem.20091508

26. Chong ZZ, Maiese K. The Src homology 2 domain tyrosine phosphatases SHP-1 and SHP-2: diversified control of cell growth, inflammation, and injury. Histol Histopathol. (2007) 22:1251-67. doi: 10.14670/HH-22.1251

27. Lorenz U. SHP-1 and SHP-2 in T cells: two phosphatases functioning at many levels. Immunol Rev. (2009) 228:342-59. doi: 10.1111/j.1600-065X.2008.00760.x

28. Jonsson MV, Szodoray P, Jellestad S, Jonsson R, Skarstein K. Association between circulating levels of the novel TNF family members APRIL and BAFF and lymphoid organization in primary Sjogren's syndrome. J Clin Immunol. (2005) 25:189-201. doi: 10.1007/s10875-005-4091-5

29. Pers JO, Daridon C, Devauchelle V, Jousse S, Saraux A, Jamin C, et al. BAFF overexpression is associated with autoantibody production in autoimmune diseases. Ann N Y Acad Sci. (2005) 1050:34-9. doi: 10.1196/annals.1313.004

30. Seyler TM, Park YW, Takemura S, Bram RJ, Kurtin PJ, Goronzy JJ, et al. BLyS and APRIL in rheumatoid arthritis. J Clin Invest. (2005) 115:3083-92. doi: $10.1172 /$ JCI25265

31. Stohl W, Metyas S, Tan SM, Cheema GS, Oamar B, Xu D, et al. B lymphocyte stimulator overexpression in patients with systemic lupus erythematosus: longitudinal observations. Arthritis Rheum. (2003) 48:347586. doi: 10.1002/art.11354

32. Dubey AK, Handu SS, Dubey S, Sharma P, Sharma KK, Ahmed QM. Belimumab: First targeted biological treatment for systemic lupus erythematosus. J Pharmacol Pharmacother. (2011) 2:317-9. doi: 10.4103/0976-500X.85930

33. Halpern WG, Lappin P, Zanardi T, Cai W, Corcoran M, Zhong J, et al. Chronic administration of belimumab, a BLyS antagonist, decreases tissue and peripheral blood B-lymphocyte populations in cynomolgus monkeys: pharmacokinetic, pharmacodynamic, and toxicologic effects. Toxicol Sci. (2006) 91:586-99. doi: 10.1093/toxsci/kfj148

34. Baker KP, Edwards BM, Main SH, Choi GH, Wager RE, Halpern WG, et al. Generation and characterization of LymphoStat-B, a human monoclonal antibody that antagonizes the bioactivities of B lymphocyte stimulator. Arthritis Rheum. (2003) 48:3253-65. doi: 10.1002/art.11299

35. Raje NS, Moreau P, Terpos E, Benboubker L, Grzasko N, Holstein SA, et al. Phase 2 study of tabalumab, a human anti-B-cell activating factor antibody, with bortezomib and dexamethasone in patients with previously treated multiple myeloma. Br J Haematol. (2017) 176:783-95. doi: 10.1111/bjh. 14483

36. Genovese MC, Fleischmann RM, Greenwald M, Satterwhite J, Veenhuizen $\mathrm{M}$, Xie L, et al. Tabalumab, an anti-BAFF monoclonal antibody, in patients with active rheumatoid arthritis with an inadequate response to TNF inhibitors. Ann Rheum Dis. (2013) 72:1461-8. doi: 10.1136/annrheumdis-2012-202775

37. Kim KS, Park JY, Jou I, Park SM. Functional implication of BAFF synthesis and release in gangliosides-stimulated microglia. J Leukoc Biol. (2009) 86:349-59. doi: $10.1189 / \mathrm{jlb} .1008659$
38. Li K, Yu W, Cao R, Zhu Z, Zhao G. Microglia-mediated BAFF-BAFFR ligation promotes neuronal survival in brain ischemia injury. Neuroscience (2017) 363:87-96. doi: 10.1016/j.neuroscience.2017.09.007

39. Krumbholz M, Theil D, Derfuss T, Rosenwald A, Schrader F, Monoranu CM, et al. BAFF is produced by astrocytes and up-regulated in multiple sclerosis lesions and primary central nervous system lymphoma. J Exp Med. (2005) 201:195-200. doi: 10.1084/jem.20041674

40. Kim SS, Richman DP, Zamvil SS, Agius MA. Accelerated central nervous system autoimmunity in BAFF-receptor-deficient mice. J Neurol Sci. (2011) 306:9-15. doi: 10.1016/j.jns.2011.04.008

41. Thangarajh M, Masterman T, Hillert J, Moerk S, Jonsson R. A proliferation-inducing ligand (APRIL) is expressed by astrocytes and is increased in multiple sclerosis. Scand J Immunol. (2007) 65:92-8. doi: 10.1111/j.1365-3083.2006.01867.x

42. Jagessar SA, Heijmans N, Oh L, Bauer J, Blezer EL, Laman JD, et al. Antibodies against human BLyS and APRIL attenuate EAE development in marmoset monkeys. J Neuroimmune Pharmacol. (2012) 7:557-70. doi: $10.1007 / \mathrm{s} 11481-012-9384-\mathrm{x}$

43. Mauri DN, Ebner R, Montgomery RI, Kochel KD, Cheung TC, Yu GL, et al. LIGHT, a new member of the TNF superfamily, and lymphotoxin alpha are ligands for herpesvirus entry mediator. Immunity (1998) 8:21-30. doi: 10.1016/S1074-7613(00)80455-0

44. Rooney IA, Butrovich KD, Glass AA, Borboroglu S, Benedict CA, Whitbeck JC, et al. The lymphotoxin-beta receptor is necessary and sufficient for LIGHT-mediated apoptosis of tumor cells. J Biol Chem. (2000) 275:1430715.

45. Cohavy O, Zhou J, Ware CF, Targan SR. LIGHT is constitutively expressed on $\mathrm{T}$ and NK cells in the human gut and can be induced by CD2-mediated signaling. J Immunol. (2005) 174:646-53. doi: 10.4049/jimmunol.174.2.646

46. Duhen T, Pasero C, Mallet F, Barbarat B, Olive D, Costello RT. LIGHT costimulates CD40 triggering and induces immunoglobulin secretion; a novel key partner in T cell-dependent B cell terminal differentiation. Eur J Immunol. (2004) 34:3534-41. doi: 10.1002/eji.200425598

47. Yu KY, Kwon B, Ni J, Zhai Y, Ebner R, Kwon BS. A newly identified member of tumor necrosis factor receptor superfamily (TR6) suppresses LIGHT-mediated apoptosis. J Biol Chem. (1999) 274:13733-6. doi: $10.1074 /$ jbc.274.20.13733

48. Tamada K, Shimozaki K, Chapoval AI, Zhu G, Sica G, Flies D, et al. Modulation of T-cell-mediated immunity in tumor and graft-versus-host disease models through the LIGHT co-stimulatory pathway. Nat Med. (2000) 6:283-9. doi: 10.1038/73136

49. Tamada K, Shimozaki K, Chapoval AI, Zhai Y, Su J, Chen SF, et al. LIGHT, a TNF-like molecule, costimulates $\mathrm{T}$ cell proliferation and is required for dendritic cell-mediated allogeneic T cell response. J Immunol. (2000) 164:4105-10. doi: 10.4049/jimmunol.164.8.4105

50. Harrop JA, Reddy M, Dede K, Brigham-Burke M, Lyn S, Tan KB, et al. Antibodies to TR2 (herpesvirus entry mediator), a new member of the TNF receptor superfamily, block $\mathrm{T}$ cell proliferation, expression of activation markers, and production of cytokines. J Immunol. (1998) 161:1786-94.

51. Shi G, Luo H, Wan X, Salcedo TW, Zhang J, Wu J. Mouse T cells receive costimulatory signals from LIGHT, a TNF family member. Blood (2002) 100:3279-86. doi: 10.1182/blood-2002-05-1404

52. Wan X, Zhang J, Luo H, Shi G, Kapnik E, Kim S, et al. A TNF family member LIGHT transduces costimulatory signals into human T cells. J Immunol. (2002) 169:6813-21. doi: 10.4049/jimmunol.169.12.6813

53. Bai C, Connolly B, Metzker ML, Hilliard CA, Liu X, Sandig V, et al. Overexpression of M68/DcR3 in human gastrointestinal tract tumors independent of gene amplification and its location in a four-gene cluster. Proc Natl Acad Sci USA. (2000) 97:1230-5. doi: 10.1073/pnas.97.3.1230

54. Montgomery RI, Warner MS, Lum BJ, Spear PG. Herpes simplex virus1 entry into cells mediated by a novel member of the TNF/NGF receptor family. Cell (1996) 87:427-36. doi: 10.1016/S0092-8674(00)81363-X

55. Kwon BS, Tan KB, Ni J, Oh KO, Lee ZH, Kim KK, et al. A newly identified member of the tumor necrosis factor receptor superfamily with a wide tissue distribution and involvement in lymphocyte activation. J Biol Chem. (1997) 272:14272-6. doi: 10.1074/jbc.272.22.14272

56. Marsters SA, Ayres TM, Skubatch M, Gray CL, Rothe M, Ashkenazi A. Herpesvirus entry mediator, a member of the tumor necrosis factor receptor 
(TNFR) family, interacts with members of the TNFR-associated factor family and activates the transcription factors NF-kappaB and AP-1. J Biol Chem. (1997) 272:14029-32. doi: 10.1074/jbc.272.22.14029

57. Remouchamps C, Boutaffala L, Ganeff C, Dejardin E. Biology and signal transduction pathways of the Lymphotoxin-alphabeta/LTbetaR system. Cytokine Growth Factor Rev. (2011) 22:301-10. doi: 10.1016/j.cytogfr.2011.11.007S1359-6101(11)00060-8

58. Haybaeck J, Zeller N, Wolf MJ, Weber A, Wagner U, Kurrer MO, et al. A lymphotoxin-driven pathway to hepatocellular carcinoma. Cancer Cell (2009) 16:295-308. doi: 10.1016/j.ccr.2009.08.021

59. Lowes KN, Croager EJ, Abraham LJ, Olynyk JK, Yeoh GC. Upregulation of lymphotoxin beta expression in liver progenitor (oval) cells in chronic hepatitis C. Gut (2003) 52:1327-32. doi: 10.1136/gut.52.9.1327

60. De Togni P, Goellner J, Ruddle NH, Streeter PR, Fick A, Mariathasan S, et al. Abnormal development of peripheral lymphoid organs in mice deficient in lymphotoxin. Science (1994) 264:703-07. doi: 10.1126/science.8171322

61. Banks TA, Rouse BT, Kerley MK, Blair PJ, Godfrey VL, Kuklin NA, et al. Lymphotoxin-alpha-deficient mice. Effects on secondary lymphoid organ development and humoral immune responsiveness. J Immunol. (1995) 155:1685-93.

62. Wang YG, Kim KD, Wang J, Yu P, Fu YX. Stimulating lymphotoxin beta receptor on the dendritic cells is critical for their homeostasis and expansion. J Immunol. (2005) 175:6997-7002.

63. Kabashima K, Banks TA, Ansel KM, Lu TT, Ware CF, Cyster JG. Intrinsic lymphotoxin-beta receptor requirement for homeostasis of lymphoid tissue dendritic cells. Immunity (2005) 22:439-50. doi: 10.1016/j.immuni.2005.02.007

64. Ganeff C, Remouchamps C, Boutaffala L, Benezech C, Galopin G, Vandepaer $\mathrm{S}$, et al. Induction of the alternative NF-kappaB pathway by lymphotoxin alphabeta (LTalphabeta) relies on internalization of LTbeta receptor. Mol Cell Biol. (2011) 31:4319-34. doi: 10.1128/MCB.05033-11

65. Force WR, Glass AA, Benedict CA, Cheung TC, Lama J, Ware CF. Discrete signaling regions in the lymphotoxin-beta receptor for tumor necrosis factor receptor-associated factor binding, subcellular localization, and activation of cell death and NF-kappaB pathways. J Biol Chem. (2000) 275:11121-9. doi: $10.1074 / \mathrm{jbc} .275 .15 .11121$

66. Dejardin E, Droin NM, Delhase M, Haas E, Cao Y, Makris C, et al. The lymphotoxin-beta receptor induces different patterns of gene expression via two NF-kappaB pathways. Immunity (2002) 17:525-35.

67. Jang SW, Lim SG, Suk K, Lee WH. Activation of lymphotoxin-beta receptor enhances the LPS-induced expression of IL-8 through NF-kappaB and IRF-1. Immunol Lett. (2015) 165:63-9. doi: 10.1016/j.imlet.2015.04.001

68. Zhang J, Salcedo TW, Wan X, Ullrich S, Hu B, Gregorio T, et al. Modulation of T-cell responses to alloantigens by TR6/DcR3. J Clin Invest. (2001) 107:1459-68. doi: 10.1172/JCI12159

69. Hsu MJ, Lin WW, Tsao WC, Chang YC, Hsu TL, Chiu AW, et al. Enhanced adhesion of monocytes via reverse signaling triggered by decoy receptor 3 . Exp Cell Res. (2004) 292:241-51. doi: 10.1016/j.yexcr.2003.09.019

70. Lim SG, Suk K, Lee WH. Reverse signaling from LIGHT promotes pro-inflammatory responses in the human monocytic leukemia cell line, THP-1. Cell Immunol. (2013) 285:10-7. doi: 10.1016/j.cellimm.2013. 08.002

71. Bello-Morales R, Crespillo AJ, Garcia B, Dorado LA, Martin B, Tabares E, et al. The effect of cellular differentiation on HSV1 infection of oligodendrocytic cells. PLoS ONE (2014) 9:e89141. doi: 10.1371/journal.pone.0089141

72. Aebischer J, Cassina P, Otsmane B, Moumen A, Seilhean D, Meininger V, et al. IFNgamma triggers a LIGHT-dependent selective death of motoneurons contributing to the non-cell-autonomous effects of mutant SOD1. Cell Death Differ. (2011) 18:754-68. doi: 10.1038/cdd.2010.143

73. Mana P, Linares D, Silva DG, Fordham S, Scheu S, Pfeffer K, et al. LIGHT (TNFSF14/CD258) is a decisive factor for recovery from experimental autoimmune encephalomyelitis. J Immunol. (2013) 191:15463. doi: 10.4049/jimmunol.1203016

74. Nocentini G, Giunchi L, Ronchetti S, Krausz LT, Bartoli A, Moraca R, et al. A new member of the tumor necrosis factor/nerve growth factor receptor family inhibits T cell receptor-induced apoptosis. Proc Natl Acad Sci USA. (1997) 94:6216-21. doi: 10.1073/pnas.94.12.6216
75. Hwang H, Lee S, Lee WH, Lee HJ, Suk K. Stimulation of glucocorticoidinduced tumor necrosis factor receptor family-related protein ligand (GITRL) induces inflammatory activation of microglia in culture. J Neurosci Res. (2010) 88:2188-96. doi: 10.1002/jnr.22378

76. Bae E, Kim WJ, Kang YM, Suk K, Koh EM, Cha HS, et al. Glucocorticoid-induced tumour necrosis factor receptor-related proteinmediated macrophage stimulation may induce cellular adhesion and cytokine expression in rheumatoid arthritis. Clin Exp Immunol. (2007) 148:410-8. doi: 10.1111/j.1365-2249.2007.03363.x

77. Kim WJ, Bae EM, Kang YJ, Bae HU, Hong SH, Lee J, et al. Glucocorticoidinduced TNFR family-related protein (GITR) mediates inflammatory activation of macrophages that can destabilize atherosclerotic plaques. Immunology (2006) 119:421-9. doi: 10.1111/j.1365-2567.2006.02453.x

78. McHugh RS, Whitters MJ, Piccirillo CA, Young DA, Shevach EM, Collins M, et al. CD4(+)CD25(+) immunoregulatory T cells: gene expression analysis reveals a functional role for the glucocorticoid-induced TNF receptor. Immunity (2002) 16:311-23. doi: 10.1016/S1074-7613(02)00280-7

79. Shimizu J, Yamazaki S, Takahashi T, Ishida Y, Sakaguchi S. Stimulation of $\mathrm{CD} 25(+) \mathrm{CD} 4(+)$ regulatory $\mathrm{T}$ cells through GITR breaks immunological self-tolerance. Nat Immunol. (2002) 3:135-42. doi: 10.1038/ni759

80. Lacal PM, Petrillo MG, Ruffini F, Muzi A, Bianchini R, Ronchetti S, et al. Glucocorticoid-induced tumor necrosis factor receptor family-related ligand triggering upregulates vascular cell adhesion molecule-1 and intercellular adhesion molecule-1 and promotes leukocyte adhesion. J Pharmacol Exp Ther. (2013) 347:164-72. doi: 10.1124/jpet.113.207605

81. Nocentini G, Riccardi C. GITR: a multifaceted regulator of immunity belonging to the tumor necrosis factor receptor superfamily. Eur J Immunol. (2005) 35:1016-22. doi: 10.1002/eji.200425818

82. Kanamaru F, Youngnak P, Hashiguchi M, Nishioka T, Takahashi T, Sakaguchi $\mathrm{S}$, et al. Costimulation via glucocorticoid-induced TNF receptor in both conventional and $\mathrm{CD}_{2} 5^{+}$regulatory $\mathrm{CD} 4^{+} \mathrm{T}$ cells. J Immunol. (2004) 172:7306-14. doi: 10.4049/jimmunol.172.12.7306

83. Ronchetti S, Zollo O, Bruscoli S, Agostini M, Bianchini R, Nocentini G, et al. GITR, a member of the TNF receptor superfamily, is costimulatory to mouse T lymphocyte subpopulations. Eur J Immunol. (2004) 34:613-22. doi: 10.1002/eji.200324804

84. Tone M, Tone Y, Adams E, Yates SF, Frewin MR, Cobbold SP, et al. Mouse glucocorticoid-induced tumor necrosis factor receptor ligand is costimulatory for T cells. Proc Natl Acad Sci USA. (2003) 100:15059-64. doi: 10.1073/pnas.2334901100

85. Kwon B, Yu KY, Ni J, Yu GL, Jang IK, Kim YJ, et al. Identification of a novel activation-inducible protein of the tumor necrosis factor receptor superfamily and its ligand. J Biol Chem. (1999) 274:6056-61. doi: $10.1074 /$ jbc.274.10.6056

86. Cuzzocrea S, Ayroldi E, Di Paola R, Agostini M, Mazzon E, Bruscoli $\mathrm{S}$, et al. Role of glucocorticoid-induced TNF receptor family gene (GITR) in collagen-induced arthritis. Faseb J. (2005) 19:1253-65. doi: 10.1096/fj.04-3556com

87. Cuzzocrea S, Ronchetti S, Genovese T, Mazzon E, Agostini M, Di Paola R, et al. Genetic and pharmacological inhibition of GITR-GITRL interaction reduces chronic lung injury induced by bleomycin instillation. FASEB J. (2007) 21:117-29. doi: 10.1096/fj.06-6611 com

88. Nocentini G, Cuzzocrea S, Bianchini R, Mazzon E, Riccardi C. Modulation of acute and chronic inflammation of the lung by GITR and its ligand. Ann N Y Acad Sci. (2007) 1107:380-91. doi: 10.1196/annals.1381.040

89. Cuzzocrea S, Nocentini G, Di Paola R, Mazzon E, Ronchetti S, Genovese T, et al. Glucocorticoid-induced TNF receptor family gene (GITR) knockout mice exhibit a resistance to splanchnic artery occlusion (SAO) shock. J Leuk Biol. (2004) 76:933-40. doi: 10.1189/jlb.0204110

90. Nocentini G, Riccardi C. GITR: a modulator of immune response and inflammation. Adv Exp Med Biol. (2009) 647:156-73. doi: 10.1007/978-0-387-89520-8_11

91. Nocentini G, Ronchetti S, Petrillo MG, Riccardi C. Pharmacological modulation of GITRL/GITR system: therapeutic perspectives. $\mathrm{Br} \mathrm{J}$ Pharmacol. (2012) 165:2089-99. doi: 10.1111/j.1476-5381.2011.01753.x

92. Nocentini G, Cuzzocrea S, Genovese T, Bianchini R, Mazzon E, Ronchetti $\mathrm{S}$, et al. Glucocorticoid-induced tumor necrosis factor receptor-related (GITR)-Fc fusion protein inhibits GITR triggering and protects from the 
inflammatory response after spinal cord injury. Mol Pharmacol. (2008) 73:1610-21. doi: 10.1124/mol.107.044354

93. Bae EM, Kim WJ, Suk K, Kang YM, Park JE, Kim WY, et al. Reverse signaling initiated from GITRL induces NF-kappaB activation through ERK in the inflammatory activation of macrophages. Mol Immunol. (2008) 45:523-33. doi: 10.1016/j.molimm.2007.05.013

94. Lee HS, Shin HH, Kwon BS, Choi HS. Soluble glucocorticoid-induced tumor necrosis factor receptor (sGITR) increased MMP-9 activity in murine macrophage. J Cell Biochem. (2003) 88:1048-56. doi: 10.1002/jcb. 10456

95. Shin HH, Lee HW, Choi HS. Induction of nitric oxide synthase (NOS) by soluble glucocorticoid induced tumor necrosis factor receptor (sGITR) is modulated by IFN-gamma in murine macrophage. Exp Mol Med. (2003) 35:175-80. doi: $10.1038 / \mathrm{emm} .2003 .24$

96. Shin HH, Kwon BS, Choi HS. Recombinant glucocorticoid induced tumour necrosis factor receptor (rGITR) induced COX-2 activity in murine macrophage Raw 264.7 cells. Cytokine (2002) 19:187-92. doi: 10.1006/cyto.2002.1962

97. Shin HH, Kim SJ, Lee DS, Choi HS. Soluble glucocorticoid-induced tumor necrosis factor receptor (sGITR) stimulates osteoclast differentiation in response to receptor activator of NF-kappaB ligand (RANKL) in osteoclast cells. Bone (2005) 36:832-9. doi: 10.1016/j.bone.2005.02.014

98. Nagata S. Fas ligand-induced apoptosis. Annu Rev Genet. (1999) 33:29-55. doi: 10.1146/annurev.genet.33.1.29

99. Perl M, Chung CS, Perl U, Lomas-Neira J, de Paepe M, Cioffi WG, et al. Fas-induced pulmonary apoptosis and inflammation during indirect acute lung injury. Am J Respir Crit Care Med. (2007) 176:591-601. doi: 10.1164/rccm.200611-1743OC

100. Everett H, McFadden G. Apoptosis: an innate immune response to virus infection. Trends Microbiol. (1999) 7:160-5, doi: 10.1016/S0966-842X(99)01487-0

101. Nagata S. Apoptosis by death factor. Cell (1997) 88:355-65. doi: 10.1016/S0092-8674(00)81874-7

102. Los M, Burek CJ, Stroh C, Benedyk K, Hug H, Mackiewicz A. Anticancer drugs of tomorrow: apoptotic pathways as targets for drug design. Drug Discov Today (2003) 8:67-77. doi: 10.1016/S1359-6446(02)02563-1

103. Yonehara S, Ishii A, Yonehara M. A cell-killing monoclonal antibody (antiFas) to a cell surface antigen co-downregulated with the receptor of tumor necrosis factor. J Exp Med. (1989) 169:1747-56. doi: 10.1084/jem.169.5.1747

104. Lettau M, Paulsen M, Kabelitz D, Janssen O. FasL expression and reverse signalling. Results Probl Cell Differ. (2009) 49:49-61. doi: 10.1007/400_2008_21

105. Stahnke K, Hecker S, Kohne E, Debatin KM. CD95 (APO-1/FAS)-mediated apoptosis in cytokine-activated hematopoietic cells. Exp Hematol. (1998) 26:844-50.

106. Cheng J, Zhou T, Liu C, Shapiro JP, Brauer MJ, Kiefer MC, et al. Protection from Fas-mediated apoptosis by a soluble form of the Fas molecule. Science (1994) 263:1759-62. doi: 10.1126/science.7510905

107. Krammer PH, Arnold R, Lavrik IN. Life and death in peripheral T cells. Nat Rev Immunol. (2007) 7:532-42. doi: 10.1038/nri2115

108. Brunner T, Wasem C, Torgler R, Cima I, Jakob S, Corazza N. Fas (CD95/Apo-1) ligand regulation in $\mathrm{T}$ cell homeostasis, cell-mediated cytotoxicity and immune pathology. Semin Immunol. (2003) 15:167-76. doi: 10.1016/S1044-5323(03)00035-6

109. Igney FH, Krammer PH. Tumor counterattack: fact or fiction? Cancer Immunol Immunother. (2005) 54:1127-36. doi: 10.1007/s00262-005-0680-7

110. Niederkorn JY. See no evil, hear no evil, do no evil: the lessons of immune privilege. Nat Immunol. (2006) 7:354-9. doi: 10.1038/ni1328

111. Matute-Bello G, Liles WC, Steinberg KP, Kiener PA, Mongovin S, Chi EY, et al. Soluble Fas ligand induces epithelial cell apoptosis in humans with acute lung injury (ARDS). J Immunol. (1999) 163:2217-25.

112. Jung DY, Lee H, Jung BY, Ock J, Lee MS, Lee WH, et al. TLR4, but not TLR2, signals autoregulatory apoptosis of cultured microglia: a critical role of IFN-beta as a decision maker. J Immunol. (2005) 174:6467-76. doi: 10.4049/jimmunol.174.10.6467

113. Hamann KJ, Dorscheid DR, Ko FD, Conforti AE, Sperling AI, Rabe KF, et al. Expression of Fas (CD95) and FasL (CD95L) in human airway epithelium. Am J Respir Cell Mol Biol. (1998) 19:537-42. doi: 10.1165/ajrcmb.19.4.3100
114. Neff TA, Guo RF, Neff SB, Sarma JV, Speyer CL, Gao H, et al. Relationship of acute lung inflammatory injury to Fas/FasL system. Am J Pathol. (2005) 166:685-94. doi: 10.1016/S0002-9440(10)62290-0

115. de Oliveira GM, Diniz RL, Batista W, Batista MM, Bani Correa C, de AraujoJorge TC, et al. Fas ligand-dependent inflammatory regulation in acute myocarditis induced by Trypanosoma cruzi infection. Am J Pathol. (2007) 171:79-86. doi: 10.2353/ajpath.2007.060643

116. Altemeier WA, Zhu X, Berrington WR, Harlan JM, Liles WC. Fas (CD95) induces macrophage proinflammatory chemokine production via a MyD88dependent, caspase-independent pathway. J Leuk Biol. (2007) 82:721-8. doi: 10.1189/jlb.1006652

117. Miwa K, Asano M, Horai R, Iwakura Y, Nagata S, Suda T. Caspase 1independent IL-1beta release and inflammation induced by the apoptosis inducer Fas ligand. Nat Med. (1998) 4:1287-92. doi: 10.1038/3276

118. Park DR, Thomsen AR, Frevert CW, Pham U, Skerrett SJ, Kiener PA, et al. Fas (CD95) induces proinflammatory cytokine responses by human monocytes and monocyte-derived macrophages. J Immunol. (2003) 170:6209-16. doi: 10.4049/jimmunol.170.12.6209

119. Ma Y, Liu H, Tu-Rapp H, Thiesen HJ, Ibrahim SM, Cole SM, et al. Fas ligation on macrophages enhances IL-1R1-Toll-like receptor 4 signaling and promotes chronic inflammation. Nat Immunol. (2004) 5:3807. doi: $10.1038 /$ ni1054

120. Freiberg RA, Spencer DM, Choate KA, Duh HJ, Schreiber SL, Crabtree GR, et al. Fas signal transduction triggers either proliferation or apoptosis in human fibroblasts. J Investig Dermatol. (1997) 108:215-9. doi: 10.1111/1523-1747.ep12334273

121. Jelaska A, Korn JH. Anti-Fas induces apoptosis and proliferation in human dermal fibroblasts: differences between foreskin and adult fibroblasts. J Cell Physiol. (1998) 175:19-29. doi: 10.1002/(SICI)10974652(199804)175:1<19::AID-JCP3>3.0.CO;2-F

122. Alderson MR, Armitage RJ, Maraskovsky E, Tough TW, Roux E, Schooley $\mathrm{K}$, et al. Fas transduces activation signals in normal human T lymphocytes. $J$ Exp Med. (1993) 178:2231-5. doi: 10.1084/jem.178.6.2231

123. Alam A, Cohen LY, Aouad S, Sekaly RP. Early activation of caspases during $\mathrm{T}$ lymphocyte stimulation results in selective substrate cleavage in nonapoptotic cells. J Exp Med. (1999) 190:1879-90. doi: $10.1084 /$ jem.190.12.1879

124. Kennedy NJ, Kataoka T, Tschopp J, Budd RC. Caspase activation is required for T cell proliferation. J Exp Med. (1999) 190:1891-6. doi: $10.1084 /$ jem.190.12.1891

125. Miossec C, Dutilleul V, Fassy F, Diu-Hercend A. Evidence for CPP32 activation in the absence of apoptosis during $\mathrm{T}$ lymphocyte stimulation. $J$ Biol Chem. (1997) 272:13459-62. doi: 10.1074/jbc.272.21.13459

126. Wilhelm S, Wagner H, Hacker G. Activation of caspase-3-like enzymes in non-apoptotic T cells. Eur J Immunol. (1998) 28:891-900. doi: 10.1002/ (SICI)1521-4141(199803)28:03<891::AID-IMMU891>3.0.CO;2-X

127. Lee SM, Kim EJ, Suk K, Lee WH. Stimulation of Fas (CD95) induces production of pro-inflammatory mediators through ERK/JNK-dependent activation of NF-kappaB in THP-1 cells. Cell Immunol. (2011) 271:157-62. doi: 10.1016/j.cellimm.2011.06.019

128. Sun M, Lee S, Karray S, Levi-Strauss M, Ames KT, Fink PJ. Cutting edge: two distinct motifs within the Fas ligand tail regulate Fas ligand-mediated costimulation. J Immunol. (2007) 179:5639-43. doi: 10.4049/jimmunol.179.9.5639

129. Hane M, Lowin B, Peitsch M, Becker K, Tschopp J. Interaction of peptides derived from the Fas ligand with the Fyn-SH3 domain. FEBS Lett. (1995) 373:265-8. doi: 10.1016/0014-5793(95)01051-F

130. Wenzel J, Sanzenbacher R, Ghadimi M, Lewitzky M, Zhou Q, Kaplan DR, et al. Multiple interactions of the cytosolic polyproline region of the CD95 ligand: hints for the reverse signal transduction capacity of a death factor. FEBS Lett. (2001) 509:255-62. doi: 10.1016/S0014-5793(01)03174-X

131. Blott EJ, Bossi G, Clark R, Zvelebil M, Griffiths GM. Fas ligand is targeted to secretory lysosomes via a proline-rich domain in its cytoplasmic tail. J Cell Sci. (2001) 114:2405-16.

132. Baum W, Kirkin V, Fernandez SB, Pick R, Lettau M, Janssen O, et al. Binding of the intracellular Fas ligand (FasL) domain to the adaptor protein PSTPIP results in a cytoplasmic localization of FasL. J Biol Chem. (2005) 280:40012-24. doi: 10.1074/jbc.M502222200 
133. Sun M, Ames KT, Suzuki I, Fink PJ. The cytoplasmic domain of Fas ligand costimulates TCR signals. J Immunol. (2006) 177:1481-91. doi: 10.4049/jimmunol.177.3.1481

134. Boursalian TE, Fink PJ. Mutation in fas ligand impairs maturation of thymocytes bearing moderate affinity T cell receptors. J Exp Med. (2003) 198:349-60. doi: 10.1084/jem.20030220

135. Suzuki I, Fink PJ. Maximal proliferation of cytotoxic T lymphocytes requires reverse signaling through Fas ligand. J Exp Med. (1998) 187:123-8. doi: 10.1084/jem.187.1.123

136. Suzuki I, Martin S, Boursalian TE, Beers C, Fink PJ. Fas ligand costimulates the in vivo proliferation of $\mathrm{CD} 8^{+} \mathrm{T}$ cells. J Immunol. (2000) 165:5537-43. doi: 10.4049/jimmunol.165.10.5537

137. Suzuki I, Fink PJ. The dual functions of fas ligand in the regulation of peripheral CD8 ${ }^{+}$and CD4 ${ }^{+}$T cells. Proc Natl Acad Sci USA. (2000) 97:170712. doi: $10.1073 /$ pnas. 97.4 .1707

138. Desbarats J, Duke RC, Newell MK. Newly discovered role for Fas ligand in the cell-cycle arrest of $\mathrm{CD}^{+}{ }^{+} \mathrm{T}$ cells. Nat Med. (1998) 4:1377-82. doi: $10.1038 / 3965$

139. Cahuzac N, Baum W, Kirkin V, Conchonaud F, Wawrezinieck L, Marguet D, et al. Fas ligand is localized to membrane rafts, where it displays increased cell death-inducing activity. Blood (2006) 107:2384-91. doi: 10.1182/blood-2005-07-2883

140. Kolben T, Jeschke U, Reimer T, Karsten N, Schmoeckel E, Semmlinger A, et al. Induction of apoptosis in breast cancer cells in vitro by Fas ligand reverse signaling. J Cancer Res Clin Oncol. (2018) 144:249-56. doi: $10.1007 / \mathrm{s} 00432-017-2551-y$

141. Lee SM, Kim EJ, Suk K, Lee WH. Stimulation of FasL induces production of proinflammatory mediators through activation of mitogen-activated protein kinases and nuclear factor-kappaB in THP-1 cells. Inflammation (2012) 35:1-10. doi: 10.1007/s10753-010-9283-3

142. Jha MK, Jo M, Kim JH, Suk K. Microglia-astrocyte crosstalk: an intimate molecular conversation. Neuroscientist (2018). doi: 10.1177/1073858418783959. [Epub ahead of print].

143. Badie B, Schartner J, Prabakaran S, Paul J, Vorpahl J. Expression of Fas ligand by microglia: possible role in glioma immune evasion. J Neuroimmunol. (2001) 120:19-24. doi: 10.1016/S0165-5728(01)00361-7

144. Choi C, Park JY, Lee J, Lim JH, Shin EC, Ahn YS, et al. Fas ligand and Fas are expressed constitutively in human astrocytes and the expression increases with IL-1, IL-6, TNF-alpha, or IFN-gamma. J Immunol. (1999) 162:1889-95.

145. Lee SJ, Zhou T, Choi C, Wang Z, Benveniste EN. Differential regulation and function of Fas expression on glial cells. J Immunol. (2000) 164:1277-85. doi: 10.4049/jimmunol.164.3.1277

146. Wang X, Haroon F, Karray S, Martina D, Schluter D. Astrocytic Fas ligand expression is required to induce $\mathrm{T}$-cell apoptosis and recovery from experimental autoimmune encephalomyelitis. Eur J Immunol. (2013) 43:115-24. doi: 10.1002/eji.201242679

147. Okuda Y, Sakoda S, Fujimura H, Nagata S, Yanagihara T, Bernard CC. Intrathecal administration of neutralizing antibody against Fas ligand suppresses the progression of experimental autoimmune encephalomyelitis. Biochem Biophys Res Commun. (2000) 275:164-8. doi: 10.1006/bbrc.2000.3279

148. Fragoso-Loyo H, Atisha-Fregoso Y, Nunez-Alvarez CA, Llorente L. Utility of TWEAK to assess neuropsychiatric disease activity in systemic lupus erhytematosus. Lupus (2016) 25:364-9. doi: 10. 1177/0961203315610206

149. Wiley SR, Winkles JA. TWEAK, a member of the TNF superfamily, is a multifunctional cytokine that binds the TweakR/Fn14 receptor. Cytokine Growth Factor Rev. (2003) 14:241-9. doi: 10.1016/S1359-6101(03)00019-4

150. Burkly LC. TWEAK/Fn14 axis: the current paradigm of tissue injuryinducible function in the midst of complexities. Semin Immunol. (2014) 26:229-36. doi: 10.1016/j.smim.2014.02.006

151. Chicheportiche Y, Bourdon PR, Xu H, Hsu YM, Scott H, Hession C, et al. TWEAK, a new secreted ligand in the tumor necrosis factor family that weakly induces apoptosis. J Biol Chem. (1997) 272:32401-10. doi: $10.1074 / \mathrm{jbc} .272 .51 .32401$

152. Liu Q, Xiao S, Xia Y. TWEAK/Fn14 activation participates in skin inflammation. Mediators Inflamm. (2017) 2017:6746870. doi: $10.1155 / 2017 / 6746870$
153. Xia Y, Herlitz LC, Gindea S, Wen J, Pawar RD, Misharin A, et al. Deficiency of fibroblast growth factor-inducible 14 (Fn14) preserves the filtration barrier and ameliorates lupus nephritis. J Am Soc Nephrol. (2015) 26:1053-70. doi: 10.1681/ASN.2014030233

154. Hu G, Zeng W, Xia Y. TWEAK/Fn14 signaling in tumors. Tumour Biol. (2017) 39:1010428317714624. doi: 10.1177/1010428317714624

155. Sun F, Teng J, Yu P, Li W, Chang J, Xu H. Involvement of TWEAK and the NF-kappaB signaling pathway in lupus nephritis. Exp Ther Med. (2018) 15:2611-9. doi: 10.3892/etm.2018.5711

156. Armstrong CL, Galisteo R, Brown SA, Winkles JA. TWEAK activation of the non-canonical NF-kappaB signaling pathway differentially regulates melanoma and prostate cancer cell invasion. Oncotarget (2016) 7:81474-92. doi: $10.18632 /$ oncotarget.13034

157. Kolfschoten GM, Pradet-Balade B, Hahne M, Medema JP. TWE-PRIL; a fusion protein of TWEAK and APRIL. Biochem Pharmacol. (2003) 66:142732. doi: 10.1016/S0006-2952(03)00493-3

158. Daridon C, Youinou P, Pers JO. BAFF, APRIL, TWE-PRIL: who's who? Autoimmun Rev. (2008) 7:267-71. doi: 10.1016/j.autrev.2007.05.002

159. Pradet-Balade B, Medema JP, Lopez-Fraga M, Lozano JC, Kolfschoten GM, Picard A, et al. An endogenous hybrid mRNA encodes TWE-PRIL, a functional cell surface TWEAK-APRIL fusion protein. EMBO J. (2002) 21:5711-20. doi: 10.1093/emboj/cdf565

160. Howard L, Wosnitzka E, Okakpu D, White MA, Wyatt S, Davies AM. TWE-PRIL reverse signalling suppresses sympathetic axon growth and tissue innervation. Development (2018) 145:dev165936. doi: 10.1242/dev.165936

161. Desplat-Jego S, Varriale S, Creidy R, Terra R, Bernard D, Khrestchatisky $\mathrm{M}$, et al. TWEAK is expressed by glial cells, induces astrocyte proliferation and increases EAE severity. J Neuroimmunol. (2002) 133:116-23. doi: 10.1016/S0165-5728(02)00368-5

162. Saas P, Boucraut J, Walker PR, Quiquerez AL, Billot M, Desplat-Jego S, et al. TWEAK stimulation of astrocytes and the proinflammatory consequences. Glia (2000) 32:102-7. doi: 10.1002/1098-1136(200010)32:1<102::AIDGLIA100>3.0.CO;2-U

163. Mueller AM, Pedre X, Kleiter I, Hornberg M, Steinbrecher A, Giegerich G. Targeting fibroblast growth factor-inducible-14 signaling protects from chronic relapsing experimental autoimmune encephalomyelitis. $J$ Neuroimmunol. (2005) 159:55-65. doi: 10.1016/j.jneuroim.2004.10.001

164. Desplat-Jego S, Creidy R, Varriale S, Allaire N, Luo Y, Bernard $\mathrm{D}$, et al. Anti-TWEAK monoclonal antibodies reduce immune cell infiltration in the central nervous system and severity of experimental autoimmune encephalomyelitis. Clin Immunol. (2005) 117:15-23. doi: 10.1016/j.clim.2005.06.005

165. Kwon BS, Weissman SM. cDNA sequences of two inducible T-cell genes. Proc Natl Acad Sci USA. (1989) 86:1963-7. doi: 10.1073/pnas.86.6.1963

166. Schwarz H, Valbracht J, Tuckwell J, von Kempis J, Lotz M. ILA, the human $4-1 \mathrm{BB}$ homologue, is inducible in lymphoid and other cell lineages. Blood (1995) 85:1043-52.

167. Vinay DS, Kwon BS. 4-1BB signaling beyond T cells. Cell Mol Immunol. (2011) 8:281-4. doi: 10.1038/cmi.2010.82

168. Shao Z, Schwarz H. CD137 ligand, a member of the tumor necrosis factor family, regulates immune responses via reverse signal transduction. J Leuk Biol. (2011) 89:21-9. doi: 10.1189/jlb.0510315

169. Langstein J, Michel J, Fritsche J, Kreutz M, Andreesen R, Schwarz H. CD137 (ILA/4-1BB), a member of the TNF receptor family, induces monocyte activation via bidirectional signaling. J Immunol. (1998) 160:2488-94.

170. Tan JT, Whitmire JK, Ahmed R, Pearson TC, Larsen CP. 4-1BB ligand, a member of the TNF family, is important for the generation of antiviral CD8 T cell responses. J Immunol. (1999) 163:4859-68.

171. Kim YH, Choi BK, Shin SM, Kim CH, Oh HS, Park SH, et al. 4-1BB triggering ameliorates experimental autoimmune encephalomyelitis by modulating the balance between Th17 and regulatory T cells. J Immunol. (2011) 187:1120-8. doi: 10.4049/jimmunol.1002681

172. Xu DP, Sauter BV, Huang TG, Meseck M, Woo SL, Chen SH. The systemic administration of Ig-4-1BB ligand in combination with IL-12 gene transfer eradicates hepatic colon carcinoma. Gene Ther. (2005) 12:1526-33. doi: $10.1038 /$ s.gt. 3302556

173. Ju SW, Ju SG, Wang FM, Gu ZJ, Qiu YH, Yu GH, et al. A functional anti-human 4-1BB ligand monoclonal antibody that enhances proliferation 
of monocytes by reverse signaling of 4-1BBL. Hybrid Hybridomics (2003) 22:333-8. doi: 10.1089/153685903322538872

174. Kim DK, Lee SC, Lee HW. CD137 ligand-mediated reverse signals increase cell viability and cytokine expression in murine myeloid cells: involvement of mTOR/p70S6 kinase and Akt. Eur J Immunol. (2009) 39:2617-28. doi: 10.1002/eji.200939292

175. Tu TH, Kim CS, Nam-Goong IS, Nam CW, Kim YI, Goto T, et al. 4-1BBL signaling promotes cell proliferation through reprogramming of glucose metabolism in monocytes/macrophages. FEBS J. (2015) 282:146880. doi: $10.1111 /$ febs.13236

176. Saito K, Ohara N, Hotokezaka H, Fukumoto S, Yuasa K, Naito M, et al. Infection-induced up-regulation of the costimulatory molecule 4$1 \mathrm{BB}$ in osteoblastic cells and its inhibitory effect on M-CSF/RANKLinduced in vitro osteoclastogenesis. J Biol Chem. (2004) 279:13555-63. doi: 10.1074/jbc.M303791200

177. Sollner L, Shaqireen DOKMM, Wu JT, Schwarz H. Signal transduction mechanisms of CD137 ligand in human monocytes. Cell Signal. (2007) 19:1899-908. doi: 10.1016/j.cellsig.2007.04.014

178. Schwarz H. Biological activities of reverse signal transduction through CD137 ligand. J Leuk Biol. (2005) 77:281-6. doi: 10.1189/jlb.0904558

179. Kim JD, Lee EA, Quang NN, Cho HR, Kwon B. Recombinant TAT-CD137 ligand cytoplasmic domain fusion protein induces the production of IL-6 and TNF-alpha in peritoneal macrophages. Immune Netw. (2011) 11:216-22. doi: 10.4110/in.2011.11.4.216

180. Kwajah MMS, Schwarz H. CD137 ligand signaling induces human monocyte to dendritic cell differentiation. Eur J Immunol. (2010) 40:1938-49. doi: 10.1002/eji.200940105

181. Moh MC, Lorenzini PA, Gullo C, Schwarz H. Tumor necrosis factor receptor 1 associates with CD137 ligand and mediates its reverse signaling. FASEB J. (2013) 27:2957-66. doi: 10.1096/fj.12-225250

182. Bae JS, Choi JK, Moon JH, Kim EC, Croft M, Lee HW. Novel transmembrane protein 126A (TMEM126A) couples with CD137L reverse signals in myeloid cells. Cell Signal. (2012) 24:2227-36. doi: 10.1016/j.cellsig.2012.07.021

183. Ju S, Ge Y, Qiu H, Lu B, Qiu Y, Fu J, et al. A novel approach to induce human DCs from monocytes by triggering 4-1BBL reverse signaling. Int Immunol. (2009) 21:1135-44. doi: 10.1093/intimm/dxp077dxp077

184. Kang SW, Lee SC, Park SH, Kim J, Kim HH, Lee HW, et al. Anti-CD137 suppresses tumor growth by blocking reverse signaling by CD137 LIGAND. Cancer Res. (2017) 77:5989-6000. doi: 10.1158/0008-5472.CAN-17-0610

185. Rahman MH, Kim MS, Lee IK, Yu R, Suk K. Interglial Crosstalk in Obesity-Induced Hypothalamic Inflammation. Front Neurosci. (2018) 12:939. doi: 10.3389/fnins.2018.00939

186. Kim J, Kwon YH, Kim CS, Tu TH, Kim BS, Joe Y, et al. The involvement of 4-1BB/4-1BBL signaling in glial cell-mediated hypothalamic inflammation in obesity. FEBS Open Bio. (2018) 8:843-53. doi: 10.1002/2211-5463.12426

187. Domonkos A, Udvardy A, Laszlo L, Nagy T, Duda E. Receptor-like properties of the $26 \mathrm{kDa}$ transmembrane form of TNF. Eur Cytokine Netw. (2001) 12:411-9.

188. Watts AD, Hunt NH, Wanigasekara Y, Bloomfield G, Wallach D, Roufogalis $\mathrm{BD}$, et al. A casein kinase I motif present in the cytoplasmic domain of members of the tumour necrosis factor ligand family is implicated in 'reverse signalling'. EMBO J. (1999) 18:2119-26. doi: 10.1093/emboj/18.8.2119

189. Pocsik E, Duda E, Wallach D. Phosphorylation of the $26 \mathrm{kDa}$ TNF precursor in monocytic cells and in transfected HeLa cells. J Inflamm. (1995) 45:152-60.

190. Juhasz K, Zvara A, Lipp AM, Nimmervoll B, Sonnleitner A, Balogi Z, et al. Casein kinase 2 -interacting protein-1, an inflammatory signaling molecule interferes with TNF reverse signaling in human model cells. Immunol Lett. (2013) 152:55-64. doi: 10.1016/j.imlet.2013.04.001

191. Eissner G, Kirchner S, Lindner H, Kolch W, Janosch P, Grell M, et al. Reverse signaling through transmembrane TNF confers resistance to lipopolysaccharide in human monocytes and macrophages. J Immunol. (2000) 164:6193-8. doi: 10.4049/jimmunol.164.12.6193

192. Kirchner S, Boldt S, Kolch W, Haffner S, Kazak S, Janosch P, et al. LPS resistance in monocytic cells caused by reverse signaling through transmembrane TNF (mTNF) is mediated by the MAPK/ERK pathway. $J$ Leuk Biol. (2004) 75:324-31. doi: 10.1189/jlb.0703343jlb.0703343
193. Deora A, Hegde S, Lee J, Choi CH, Chang Q, Lee C, et al. Transmembrane TNF-dependent uptake of anti-TNF antibodies. MAbs (2017) 9:680-95. doi: 10.1080/19420862.2017.1304869

194. Catrina AI, Trollmo C, af Klint E, Engstrom M, Lampa J, Hermansson Y, et al. Evidence that anti-tumor necrosis factor therapy with both etanercept and infliximab induces apoptosis in macrophages, but not lymphocytes, in rheumatoid arthritis joints: extended report. Arthritis Rheum. (2005) 52:61-72. doi: 10.1002/art.20764

195. Meusch U, Rossol M, Baerwald C, Hauschildt S, Wagner U. Outside-toinside signaling through transmembrane tumor necrosis factor reverses pathologic interleukin-1beta production and deficient apoptosis of rheumatoid arthritis monocytes. Arthritis Rheum. (2009) 60:2612-21. doi: 10.1002/art. 24778

196. Wijbrandts CA, Remans PH, Klarenbeek PL, Wouters D, van den Bergh Weerman MA, Smeets TJ, et al. Analysis of apoptosis in peripheral blood and synovial tissue very early after initiation of infliximab treatment in rheumatoid arthritis patients. Arthritis Rheum. (2008) 58:3330-9. doi: 10.1002/art.23989

197. Migone TS, Zhang J, Luo X, Zhuang L, Chen C, Hu B, et al. TL1A is a TNFlike ligand for DR3 and TR6/DcR3 and functions as a T cell costimulator. Immunity (2002) 16:479-92. doi: 10.1016/S1074-7613(02)00283-2

198. Pitti RM, Marsters SA, Lawrence DA, Roy M, Kischkel FC, Dowd P, et al. Genomic amplification of a decoy receptor for Fas ligand in lung and colon cancer. Nature (1998) 396:699-703. doi: 10.1038/25387

199. Connolly K, Cho YH, Duan R, Fikes J, Gregorio T, LaFleur DW, et al. In vivo inhibition of Fas ligand-mediated killing by TR6, a Fas ligand decoy receptor. J Pharmacol Exp Ther. (2001) 298:25-33.

200. Hsu TL, Chang YC, Chen SJ, Liu YJ, Chiu AW, Chio CC, et al. Modulation of dendritic cell differentiation and maturation by decoy receptor 3. J Immunol. (2002) 168:4846-53. doi: 10.4049/jimmunol.168.10.4846

201. Yang CR, Wang JH, Hsieh SL, Wang SM, Hsu TL, Lin WW. Decoy receptor 3 (DcR3) induces osteoclast formation from monocyte/macrophage lineage precursor cells. Cell Death Differ. (2004) 11 Suppl. 1:S97-107. doi: 10.1038/sj.cdd.4401403

202. Muck C, Herndler-Brandstetter D, Micutkova L, Grubeck-Loebenstein B, Jansen-Durr P. Two functionally distinct isoforms of TL1A (TNFSF15) generated by differential ectodomain shedding. J Gerontol A Biol Sci Med Sci. (2010) 65:1165-80. doi: 10.1093/gerona/glq129

203. Sidhu-Varma M, Shih DQ, Targan SR. Differential levels of Tlla affect the expansion and function of regulatory $\mathrm{T}$ cells in modulating murine colitis. Inflamm Bowel Dis. (2016) 22:548-59. doi: 10.1097/MIB.0000000000000653

204. Weinberg AD, Vella AT, Croft M. OX-40: life beyond the effector T cell stage. Semin Immunol. (1998) 10:471-80. doi: 10.1006/smim.1998.0146

205. Baum PR, Gayle RB III, Ramsdell F, Srinivasan S, Sorensen RA, Watson ML, et al. Molecular characterization of murine and human OX40/OX40 ligand systems: identification of a human OX40 ligand as the HTLV-1-regulated protein gp34. EMBO J. (1994) 13:3992-4001. doi: 10.1002/j.1460-2075.1994.tb06715.x

206. Sun G, Sun X, Li W, Liu K, Tian D, Dong Y, et al. Critical role of OX40 in the expansion and survival of CD4 T-cell-derived double-negative T cells. Cell Death Dis. (2018) 9:616. doi: 10.1038/s41419-018-0659-X

207. Imura A, Hori $\mathrm{T}$, Imada $\mathrm{K}$, Ishikawa $\mathrm{T}$, Tanaka $\mathrm{Y}$, Maeda $\mathrm{M}$, et al. The human OX40/gp34 system directly mediates adhesion of activated $\mathrm{T}$ cells to vascular endothelial cells. J Exp Med. (1996) 183:2185-95. doi: 10.1084/jem.183.5.2185

208. Godfrey WR, Fagnoni FF, Harara MA, Buck D, Engleman EG. Identification of a human OX-40 ligand, a costimulator of $\mathrm{CD}^{+} \mathrm{T}$ cells with homology to tumor necrosis factor. J Exp Med. (1994) 180:757-62. doi: 10.1084/jem.180.2.757

209. Barrios CS, Johnson BD, Henderson JD, Fink JN, Kelly KJ, Kurup VP. The costimulatory molecules CD80, CD86 and OX40L are up-regulated in Aspergillus fumigatus sensitized mice. Clin Exp Immunol. (2005) 142:24250. doi: 10.1111/j.1365-2249.2005.02905.x

210. Marinelarena A, Bhattacharya P, Kumar P, Maker AV, Prabhakar BS. Identification of a novel OX40L $(+)$ dendritic cell subset that selectively expands regulatory $\mathrm{T}$ cells. Sci Rep. (2018) 8:14940. doi: 10.1038/s41598-018-33307-z 
211. Kumar P, Marinelarena A, Raghunathan D, Ragothaman VK, Saini S, Bhattacharya P, et al. Critical role of OX40 signaling in the TCR-independent phase of human and murine thymic Treg generation. Cell Mol Immunol. (2018) 16:138-53. doi: 10.1038/cmi.2018.8

212. Gramaglia I, Weinberg $\mathrm{AD}$, Lemon $\mathrm{M}$, Croft M. Ox-40 ligand: a potent costimulatory molecule for sustaining primary CD4 $\mathrm{T}$ cell responses. $J$ Immunol. (1998) 161:6510-7.

213. Imura A, Hori $\mathrm{T}$, Imada $\mathrm{K}$, Kawamata $\mathrm{S}$, Tanaka $\mathrm{Y}$, Imamura $\mathrm{S}$, et al. OX40 expressed on fresh leukemic cells from adult T-cell leukemia patients mediates cell adhesion to vascular endothelial cells: implication for the possible involvement of OX40 in leukemic cell infiltration. Blood (1997) 89:2951-8.

214. Souza HS, Elia CC, Spencer J, MacDonald TT. Expression of lymphocyteendothelial receptor-ligand pairs, alpha4beta7/MAdCAM-1 and OX40/OX40 ligand in the colon and jejunum of patients with inflammatory bowel disease. Gut (1999) 45:856-63. doi: 10.1136/gut.45.6.856

215. Stuber E, Neurath M, Calderhead D, Fell HP, Strober W. Cross-linking of OX40 ligand, a member of the TNF/NGF cytokine family, induces proliferation and differentiation in murine splenic B cells. Immunity (1995) 2:507-21. doi: 10.1016/1074-7613(95)90031-4

216. Stuber E, Strober W. The T cell-B cell interaction via OX40-OX40L is necessary for the T cell-dependent humoral immune response. J Exp Med. (1996) 183:979-89. doi: 10.1084/jem.183.3.979

217. Fouladi S, Masjedi M, M GH, Ghasemi R, Eskandari N. Correlation of OX40 ligand on B cells with serum total IgE and IL-4 levels by CD4(+) T cells in allergic rhinitis. Allergol Immunopathol (Madr). (2018). doi: 10.1016/j.aller.2018.07.003. [Epub ahead of print].

218. Ohshima Y, Tanaka Y, Tozawa H, Takahashi Y, Maliszewski C, Delespesse G. Expression and function of OX40 ligand on human dendritic cells. $J$ Immunol. (1997) 159:3838-48.

219. Gauchat JF, Aubry JP, Mazzei G, Life P, Jomotte T, Elson G, et al. Human CD40-ligand: molecular cloning, cellular distribution and regulation of expression by factors controlling IgE production. FEBS Lett. (1993) 315:25966. doi: 10.1016/0014-5793(93)81175-Y

220. Freedman JE. CD40-CD40L and platelet function: beyond hemostasis. Circ Res. (2003) 92:944-6. doi: 10.1161/01.RES.0000074030.98009.FF

221. van Kooten C, Banchereau J. CD40-CD40 ligand. J Leuk Biol. (2000) 67:2-17. doi: 10.1002/jlb.67.1.2

222. Grewal IS, Flavell RA. CD40 and CD154 in cell-mediated immunity. Annu Rev Immunol. (1998) 16:111-35. doi: 10.1146/annurev.immunol.16.1.111

223. Banchereau J, Bazan F, Blanchard D, Briere F, Galizzi JP, van Kooten C, et al. The CD40 antigen and its ligand. Annu Rev Immunol. (1994) 12:881-922. doi: 10.1146/annurev.iy.12.040194.004313

224. Foy TM, Aruffo A, Bajorath J, Buhlmann JE, Noelle RJ. Immune regulation by CD40 and its ligand GP39. Annu Rev Immunol. (1996) 14:591-617. doi: 10.1146/annurev.immunol.14.1.591

225. Laman JD, de Smet BJ, Schoneveld A, van Meurs M. CD40-CD40L interactions in atherosclerosis. Immunol Today (1997) 18:272-7. doi: 10.1016/S0167-5699(97)80022-9

226. van Essen D, Kikutani H, Gray D. CD40 ligand-transduced co-stimulation of T cells in the development of helper function. Nature (1995) 378:620-3. doi: 10.1038/378620a0

227. Brenner B, Koppenhoefer U, Grassme H, Kun J, Lang F, Gulbins E. Evidence for a novel function of the CD40 ligand as a signalling molecule in T-lymphocytes. FEBS Lett. (1997) 417:301-6. doi: 10.1016/S0014-5793(97)01306-9

228. Brenner B, Koppenhoefer U, Lepple-Wienhues A, Grassme H, Muller C, Speer CP, et al. The CD40 ligand directly activates T-lymphocytes via tyrosine phosphorylation dependent PKC activation. Biochem Biophys Res Commun. (1997) 239:11-7. doi: 10.1006/bbrc.1997.7415

229. Koppenhoefer U, Brenner B, Lang F, Gulbins E. The CD40-ligand stimulates T-lymphocytes via the neutral sphingomyelinase: a novel function of the CD40-ligand as signalling molecule. FEBS Lett. (1997) 414:444-8. doi: 10.1016/S0014-5793(97)01035-1

230. Nadiri A, Polyak MJ, Jundi M, Alturaihi H, Reyes-Moreno C, Hassan GS, et al. CD40 translocation to lipid rafts: signaling requirements and downstream biological events. Eur J Immunol. (2011) 41:2358-67. doi: $10.1002 /$ eji.201041143
231. Hassan GS, Merhi Y, Mourad W. CD40 ligand: a neo-inflammatory molecule in vascular diseases. Immunobiology (2012) 217:521-32. doi: 10.1016/j.imbio.2011.03.010

232. Theill LE, Boyle WJ, Penninger JM. RANK-L and RANK: T cells, bone loss, mammalian evolution. Annu Rev Immunol. (2002) 20:795-823. doi: 10.1146/annurev.immunol.20.100301.064753

233. Simonet WS, Lacey DL, Dunstan CR, Kelley M, Chang MS, Luthy R, et al. Osteoprotegerin: a novel secreted protein involved in the regulation of bone density. Cell (1997) 89:309-19. doi: 10.1016/S0092-8674(00)80209-3

234. Baud'huin M, Duplomb L, Teletchea S, Lamoureux F, Ruiz-Velasco C, Maillasson $\mathrm{M}$, et al. Osteoprotegerin: multiple partners for multiple functions. Cytokine Growth Factor Rev. (2013) 24:401-9. doi: 10.1016/j.cytogfr.2013.06.001

235. Sattler AM, Schoppet M, Schaefer JR, Hofbauer LC. Novel aspects on RANK ligand and osteoprotegerin in osteoporosis and vascular disease. Calcif Tissue Int. (2004) 74:103-6. doi: 10.1007/s00223-003-0011-y

236. Wong BR, Josien R, Choi Y. TRANCE is a TNF family member that regulates dendritic cell and osteoclast function. J Leuk Biol. (1999) 65:715-24. doi: 10.1002/jlb.65.6.715

237. Hanada R, Leibbrandt A, Hanada T, Kitaoka S, Furuyashiki T, Fujihara H, et al. Central control of fever and female body temperature by RANKL/RANK. Nature (2009) 462:505-9. doi: 10.1038/nature08596

238. Fata JE, Kong YY, Li J, Sasaki T, Irie-Sasaki J, Moorehead RA, et al. The osteoclast differentiation factor osteoprotegerin-ligand is essential for mammary gland development. Cell (2000) 103:41-50. doi: 10.1016/S0092-8674(00)00103-3

239. Secchiero P, Corallini F, Barbarotto E, Melloni E, di Iasio MG, Tiribelli M, et al. Role of the RANKL/RANK system in the induction of interleukin-8 (IL8) in B chronic lymphocytic leukemia (B-CLL) cells. J Cell Physiol. (2006) 207:158-64. doi: 10.1002/jcp.20547

240. Chen NJ, Huang MW, Hsieh SL. Enhanced secretion of IFN-gamma by activated Th1 cells occurs via reverse signaling through TNFrelated activation-induced cytokine. J Immunol. (2001) 166:270-6. doi: 10.4049/jimmunol.166.1.270

241. Zhang S, Wang X, Li G, Chong Y, Zhang J, Guo X, et al. Osteoclast regulation of osteoblasts via RANKRANKL reverse signal transduction in vitro. $\mathrm{Mol}$ Med Rep. (2017) 16:3994-4000. doi: 10.3892/mmr.2017.7039

242. Piris M, Brown DC, Gatter KC, Mason DY. CD30 expression in non-Hodgkin's lymphoma. Histopathology (1990) 17:211-8. doi: 10.1111/j.1365-2559.1990.tb00709.x

243. Froese P, Lemke H, Gerdes J, Havsteen B, Schwarting R, Hansen H, et al. Biochemical characterization and biosynthesis of the Ki-1 antigen in Hodgkin-derived and virus-transformed human B and T lymphoid cell lines. J Immunol. (1987) 139:2081-7.

244. Biswas P, Smith CA, Goletti D, Hardy EC, Jackson RW, Fauci AS. Crosslinking of CD30 induces HIV expression in chronically infected T cells. Immunity (1995) 2:587-96. doi: 10.1016/1074-7613(95)90003-9

245. Maggi E, Annunziato F, Manetti R, Biagiotti R, Giudizi MG, Ravina A, et al. Activation of HIV expression by CD30 triggering in CD4+ $\mathrm{T}$ cells from HIV-infected individuals. Immunity (1995) 3: 251-5. doi: 10.1016/1074-7613(95)90094-2

246. Shanebeck KD, Maliszewski CR, Kennedy MK, Picha KS, Smith CA, Goodwin RG, et al. Regulation of murine B cell growth and differentiation by CD30 ligand. Eur J Immunol. (1995) 25:2147-53. doi: 10.1002/eji.1830250805

247. Nadali G, Vinante F, Ambrosetti A, Todeschini G, Veneri D, Zanotti $\mathrm{R}$, et al. Serum levels of soluble CD30 are elevated in the majority of untreated patients with Hodgkin's disease and correlate with clinical features and prognosis. J Clin Oncol. (1994) 12:793-7. doi: 10.1200/JCO.1994.12. 4.793

248. Pizzolo G, Vinante F, Morosato L, Nadali G, Chilosi M, Gandini G, et al. High serum level of the soluble form of CD30 molecule in the early phase of HIV-1 infection as an independent predictor of progression to AIDS. AIDS (1994) 8:741-5. doi: 10.1097/00002030-199406000-00003

249. Wiley SR, Goodwin RG, Smith CA. Reverse signaling via CD30 ligand. J Immunol. (1996) 157:3635-9.

250. Cerutti A, Schaffer A, Goodwin RG, Shah S, Zan H, Ely S, et al. Engagement of CD153 (CD30 ligand) by $\mathrm{CD}_{30}{ }^{+} \mathrm{T}$ cells inhibits class switch DNA 
recombination and antibody production in human $\operatorname{IgD}^{+} \operatorname{IgM}^{+}$B cells. $J$ Immunol. (2000) 165:786-94. doi: 10.4049/jimmunol.165.2.786

251. Borst J, Hendriks J, Xiao Y. CD27 and CD70 in T cell and B cell activation. Current Opin Immunol. (2005) 17:275-81. doi: 10.1016/j.coi.2005. 04.004

252. van Oosterwijk MF, Juwana $H$, Arens R, Tesselaar K, van Oers MH, Eldering E, et al. CD27-CD70 interactions sensitise naive $\mathrm{CD} 4^{+} \mathrm{T}$ cells for IL-12-induced Th1 cell development. Int Immunol. (2007) 19:713-8. doi: $10.1093 /$ intimm/dxm033

253. Welten SP, Redeker A, Franken KL, Benedict CA, Yagita H, Wensveen $\mathrm{FM}$, et al. CD27-CD70 costimulation controls $\mathrm{T}$ cell immunity during acute and persistent cytomegalovirus infection. J Virol. (2013) 87:6851-65. doi: $10.1128 /$ JVI.03305-12

254. Hendriks J, Gravestein LA, Tesselaar K, van Lier RA, Schumacher TN, Borst $\mathrm{J} . \mathrm{CD} 27$ is required for generation and long-term maintenance of $\mathrm{T}$ cell immunity. Nat Immunol. (2000) 1:433-40. doi: 10.1038/80877

255. Takeda K, Oshima H, Hayakawa Y, Akiba H, Atsuta M, Kobata T, et al. CD27mediated activation of murine NK cells. J Immunol. (2000) 164:1741-5. doi: 10.4049/jimmunol.164.4.1741
256. Al Sayed MF, Ruckstuhl CA, Hilmenyuk T, Claus C, Bourquin JP, Bornhauser BC, et al. CD70 reverse signaling enhances NK cell function and immunosurveillance in CD27-expressing B-cell malignancies. Blood (2017) 130:297-309. doi: 10.1182/blood-2016-12-756585

257. Lens SM, Drillenburg P, den Drijver BF, van Schijndel G, Pals ST, van Lier RA, et al. Aberrant expression and reverse signalling of CD70 on malignant B cells. Br J Haematol. (1999) 106:491-503. doi: 10.1046/j.1365-2141.1999.01573.x

Conflict of Interest Statement: The authors declare that the research was conducted in the absence of any commercial or financial relationships that could be construed as a potential conflict of interest.

Copyright $(2019$ Lee, Seo, Lim and Suk. This is an open-access article distributed under the terms of the Creative Commons Attribution License (CC BY). The use, distribution or reproduction in other forums is permitted, provided the original author(s) and the copyright owner(s) are credited and that the original publication in this journal is cited, in accordance with accepted academic practice. No use, distribution or reproduction is permitted which does not comply with these terms. 